\title{
Sources of nitrogen deposition in Federal Class I areas in the US
}

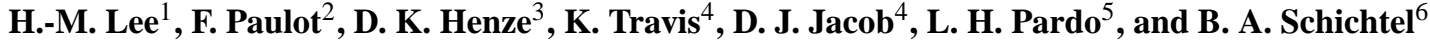 \\ ${ }^{1}$ Department of Civil, Environmental, and Architectural Engineering, University of Colorado, Boulder, CO, USA \\ ${ }^{2}$ Geophysical Fluid Dynamics Laboratory and Princeton University, Princeton, NJ, USA \\ ${ }^{3}$ Department of Mechanical Engineering, University of Colorado, Boulder, CO, USA \\ ${ }^{4}$ School of Engineering and Applied Sciences, Harvard University, Cambridge, MA, USA \\ ${ }^{5}$ USDA Forest Service, Northern Research Station, University of Vermont Aiken Center, Burlington, VT, USA \\ ${ }^{6}$ Cooperative Institute for Research in the Atmosphere, Colorado State University, Fort Collins, CO, USA
}

Correspondence to: H.-M. Lee (hyungmin.lee@ colorado.edu)

Received: 15 July 2015 - Published in Atmos. Chem. Phys. Discuss.: 27 August 2015

Revised: 4 December 2015 - Accepted: 16 December 2015 - Published: 19 January 2016

\begin{abstract}
It is desired to control excessive reactive nitrogen (Nr) deposition due to its detrimental impact on ecosystems. Using a three-dimensional atmospheric chemical transport model, GEOS-Chem, $\mathrm{Nr}$ deposition in the contiguous US and eight selected Class I areas (Voyageurs (VY), Smoky Mountain (SM), Shenandoah (SD), Big Bend (BB), Rocky Mountain (RM), Grand Teton (GT), Joshua Tree (JT), and Sequoia (SQ)) is investigated. First, modeled $\mathrm{Nr}$ deposition is compared with National Trends Network (NTN) and Clean Air Status and Trends Network (CASTNET) deposition values. The seasonality of measured species is generally well represented by the model $\left(R^{2}>0.6\right)$, except in JT. While modeled $\mathrm{Nr}$ is generally within the range of seasonal observations, large overestimates are present in sites such as SM and SD in the spring and summer (up to $0.6 \mathrm{~kg} \mathrm{~N}$ ha month ${ }^{-1}$ ), likely owing to model high-biases in surface $\mathrm{HNO}_{3}$. The contribution of non-measured species (mostly dry deposition of $\mathrm{NH}_{3}$ ) to total modeled $\mathrm{Nr}$ deposition ranges from 1 to $55 \%$. The spatial distribution of the origin of $\mathrm{Nr}$ deposited in each Class I area and the contributions of individual emission sectors are estimated using the GEOS-Chem adjoint model. We find the largest role of long-range transport for VY, where $50 \%$ (90\%) of annual $\mathrm{Nr}$ deposition originates within 670 (1670) $\mathrm{km}$ of the park. In contrast, the $\mathrm{Nr}$ emission footprint is most localized for SQ, where $50 \%(90 \%)$ of the deposition originates from within $130(370) \mathrm{km}$. Emissions from California contribute to the $\mathrm{Nr}$ deposition in remote areas in the western US (RM, GT). Mobile $\mathrm{NO}_{x}$ and livestock $\mathrm{NH}_{3}$ are found to be the major sources of $\mathrm{Nr}$ deposition in all sites except $\mathrm{BB}$, where con-
\end{abstract}

tributions of $\mathrm{NO}_{x}$ from lightning and soils to natural levels of $\mathrm{Nr}$ deposition are significant $(\sim 40 \%)$. The efficiency in terms of $\mathrm{Nr}$ deposition per kg emissions of $\mathrm{NH}_{3}-\mathrm{N}, \mathrm{NO}_{x}-\mathrm{N}$, and $\mathrm{SO}_{2}-\mathrm{S}$ are also estimated. Unique seasonal features are found in JT (opposing efficiency distributions for winter and summer), RM (large fluctuations in the range of effective regions), and $\mathrm{SD}$ (upwind $\mathrm{NH}_{3}$ emissions hindering $\mathrm{Nr}$ deposition). We also evaluate the contributions of emissions to the total area of Class I regions in critical load exceedance, and to the total magnitude of exceedance. We find that while it is effective to control emissions in the western US to reduce the area of regions in CL exceedance, it can be more effective to control emissions in the eastern US to reduce the magnitude of $\mathrm{Nr}$ deposition above the CL. Finally, uncertainty in the nitrogen deposition caused by uncertainty in the $\mathrm{NH}_{3}$ emission inventory is explored by comparing results based on two different $\mathrm{NH}_{3}$ inventories; noticeable differences in the emission inventories and thus sensitivities of up to a factor of four found in individual locations.

\section{Introduction}

Excessive deposition of reactive nitrogen $(\mathrm{Nr})$ is of interest due to its cascading impact on the environment (Vitousek et al., 1997). The primary impacts of $\mathrm{Nr}$ deposition appear in terrestrial and aquatic ecosystems as imbalanced nutrition (Galloway et al., 2003), decreased biological diversity (Sala et al., 2000; Stevens et al., 2004; Clark et al., 2013), eutrophication (Fenn et al., 2003; Duce et al., 2008), and 
acidification (Galloway et al., 2003; Sullivan et al., 2005). Each of these primary impacts lead to subsequent consequences such as disturbances in ecosystems (Galloway et al., 2003) and changes in greenhouse gas emissions and uptakes (Gruber and Galloway, 2008; Reay et al., 2008).

The potential impact of $\mathrm{Nr}$ deposition on ecosystems can be evaluated using critical loads (CLs), a quantitative estimate of an exposure to one or more pollutants below which no significant harmful effects occur over the long term (Nilsson, 1988). The magnitude of the CL varies across different types of receptors, e.g., alpine lakes, lichens in forests, alpine vegetation, etc. It can be estimated using various methods (Pardo et al., 2011), which include empirical studies (Bobbink et al., 2010), a steady-state mass balance approach (UBA, 2004), and dynamic modeling (Vries et al., 2010). Pardo et al. (2011) synthesized current research related to $\mathrm{Nr}$ deposition and comprehensively assessed empirical CLs for major ecoregions across the US.

National Parks (Organic Act of 1916, 16 USC 1-4) and wilderness areas (Wilderness Act of 1964, 16 USC 11311136 ) in the US are required to be protected to conserve natural and historic objects and the wildlife therein. Of these, Federal Class I areas are defined as those where visibility is important (Clean Air Act Amendments of 1977, 40 CFR 81). In the US, current $\mathrm{Nr}$ deposition exceeds CLs in many Class I areas. Fenn et al. (2010) estimated that one-third of the land area of California vegetation types is in excess of the CL for Nr deposition. Bowman et al. (2012) empirically determined CLs for vegetation and soils in Rocky Mountain National Park and found ongoing vegetation change due to excessive $\mathrm{Nr}$ deposition. Benedict et al. (2013a) found substantial exceedance of CLs for $\mathrm{Nr}$ deposition in Grand Teton National Park. Ellis et al. (2013) estimated that exceedances will become more pervasive in the coming decades.

It is desired to reduce the number of regions in CL exceedance and the amount of excessive $\mathrm{Nr}$ deposited above CLs. To reach this goal, it is necessary to understand the sources contributing to $\mathrm{Nr}$ deposition, which include both natural and anthropogenic emissions of $\mathrm{NO}_{x}$ and $\mathrm{NH}_{3}$. Chemical transport models (CTM) can be used to study sources of $\mathrm{Nr}$ deposition. Zhang et al. (2012) used a 3-D CTM, GEOS-Chem, to investigate the distribution, sources, and processes of $\mathrm{Nr}$ deposition in the US. By toggling emissions on and off in consecutive model simulations, they found that $\mathrm{Nr}$ deposition was dominated by contributions from domestic $\mathrm{NO}_{x}$ and $\mathrm{NH}_{3}$ emissions, followed by natural and foreign sources. While this approach provided estimates of the role of the total emissions from these sectors throughout the US, refined estimates of source contributions from specific locations can be calculated using the adjoint of a CTM, which is a computationally efficient tool for such sensitivity analysis (Henze et al., 2009). For example, Paulot et al. (2013) used the adjoint method to identify the sources and processes that control $\mathrm{Nr}$ deposition in biodiversity hotspots worldwide and in two US national parks (Cuya- hoga and Rocky Mountain) and found that anthropogenic sources dominate deposition at all continental sites and are mainly located within $1000 \mathrm{~km}$ of the hotspots themselves.

The primary purpose of this study is to evaluate the origin of $\mathrm{Nr}$ that specifically impacts Federal Class I areas throughout the US, identifying the source locations, species and sectors that contribute to both total deposition and deposition above CLs. The results can thus be used to identify how regionally specific emissions mitigation efforts will impact ecosystems in these protected areas. To accomplish this goal, we evaluate source contributions to the deposition at the collection of all Class I areas as well as eight specific regions: Voyageurs national park (VY), Smoky Mountain national park (SM), Shenandoah national park (SD), Big Bend national park (BB), Rocky Mountain national park (RM), Grand Teton national park (GT), Joshua Tree wilderness (JT), and Sequoia national park (SQ). Following Ellis et al. (2013), we use the lowest estimate of CL for these areas from Pardo et al. (2011) which are based on CLs for lichens in most regions because lichen is among the most sensitive bio-indicators of $\mathrm{N}$ in terrestrial ecosystems. These eight focus areas are selected as they have low CLs (VY, SM, SD, BB, JT: $3 \mathrm{~kg} \mathrm{Nha}^{-1} \mathrm{yr}^{-1}$, RM, GT, SQ: $2.5 \mathrm{kgNha}^{-1} \mathrm{yr}^{-1}$ ) and are thus most likely impacted by $\mathrm{Nr}$ deposition. We also choose this set of areas to highlight different spatial distributions of sources and mechanisms governing $\mathrm{Nr}$ deposition in regions of the country that are spatially disparate, are subject to a range of nitrogen emission profiles, encompass several types of ecosystems (see Fig. 1), and are subject to $\mathrm{Nr}$ deposition at levels close to or above CLs.

The secondary purpose is to evaluate the impact of uncertainties in $\mathrm{NH}_{3}$ emissions on source attribution of $\mathrm{Nr}$ deposition. $\mathrm{NH}_{3}$ emissions are known to have uncertainties of more than a factor of two in total US emissions in some seasons (e.g., Henze et al., 2009; Paulot et al., 2014). Thus, $\mathrm{NH}_{3}$ emissions inventories are often updated through top-down approaches, using constraints provided through inverse modeling of wet deposition measurements (e.g., Gilliland et al., 2003, 2006; Zhang et al., 2012; Paulot et al., 2014) or, more recently, remote-sensing observations (Zhu et al., 2013). Here we consider constraints on $\mathrm{NH}_{3}$ emissions throughout the US from Zhu et al. (2013) that were derived from 4-D variational assimilation of $\mathrm{NH}_{3}$ remote-sensing observations from the Thermal Emissions Spectrometer (TES) aboard the Aura satellite (Shephard et al., 2011). We investigate the impacts of these adjustments to $\mathrm{NH}_{3}$ emissions, relative to those from a national emissions inventory, on source attribution of $\mathrm{Nr}$ deposition in three Class I areas (VY, SD, and $\mathrm{RM})$. Another consideration is that the air-surface exchange of $\mathrm{NH}_{3}$ emissions is actually bi-directional (Nemitz et al., 2001; Sutton et al., 2007), an aspect that has recently begun to be implemented to air quality models (Cooter et al., 2010; Bash et al., 2013; Pleim et al., 2013; Zhu et al., 2015). Zhu et al. (2015) found increased net $\mathrm{NH}_{3}$ emissions in July $(5.9 \%)$ and decreased net $\mathrm{NH}_{3}$ emission in April (23.3\%) 
Table 1. NADP and CASTNET sites used for Nr deposition measurements.

\begin{tabular}{|c|c|c|c|c|}
\hline \multirow{2}{*}{ Class I area name } & \multicolumn{2}{|r|}{ NADP } & \multicolumn{2}{|c|}{ CASTNET } \\
\hline & ID & Location (lat, lon) & ID & Location (lat, lon) \\
\hline Voyaguers (VY) & MN32 & $(48.4,-92.8)$ & VOY413 & $(48.4,-92.8)$ \\
\hline Smoky Mountain (SM) & TN11 & $(35.7,-83.6)$ & GRS420 & $(35.6,-83.9)$ \\
\hline Shenandoah (SD) & VA28 & $(38.5,-78.4)$ & SHN418 & $(38.5,-78.4)$ \\
\hline \multirow[t]{2}{*}{ Big Bend (BB) } & TX04 & $(29.3,-103.2)$ & BBE401 & $(29.3,-103.2)$ \\
\hline & $\mathrm{CO} 19$ & $(40.4,-105.6)$ & ROM206 & $(40.3,-105.5)$ \\
\hline \multirow[t]{2}{*}{ Rocky Mountain (RM) ${ }^{\mathrm{a}}$} & CO89 & $(40.3,-105.7)$ & ROM406 & $(40.3,-105.5)$ \\
\hline & CO98 & $(40.3,-105.7)$ & - & - \\
\hline Pinedale (GT) & WY06 & $(42.9,-109.8)$ & PND165 & $(42.9,-109.8)$ \\
\hline Yellowstone $(\mathrm{GT})^{\mathrm{b}}$ & WY08 & $(44.9,-110.7)$ & YEL408 & $(44.6,-110.4)$ \\
\hline Joshua Tree (JT) & CA67 & $(34.1,-116.4)$ & JOT403 & $(34.1,-116.4)$ \\
\hline Sequoia (SQ) & CA75 & $(36.6,-118.4)$ & SEK430 & $(36.5,-118.8)$ \\
\hline
\end{tabular}

a Average of three collocated sites of NADP and 2 collocated sites of CASTET is used.

$\mathrm{b}$ Average of Yellowstone and Pinedale is used.

and October $(13.9 \%)$ over the US when including the bidirectional flux of $\mathrm{NH}_{3}$ in the GEOS-Chem model. As bidirectional flux of $\mathrm{NH}_{3}$ is not considered in our present work, this provides additional motivation for studying the response of $\mathrm{Nr}$ source attribution to uncertainties in $\mathrm{NH}_{3}$ emissions.

The organization of this manuscript is as follows. Modeled seasonality of $\mathrm{Nr}$ deposition is compared with measurement data in Sect. 3.1. Sensitivity analysis using the adjoint model is presented in Sect. 3.2. In Sect. 3.3, we examine the impacts of uncertainties in our model's $\mathrm{NH}_{3}$ emissions in the source attribution results. The paper concludes with summary and discussions in Sect. 4.

\section{Methods}

\subsection{Measurement data}

The National Trends Network (NTN) (http://nadp.sws.uiuc. edu) of the National Atmospheric Deposition Program (NADP, 2015) provides weekly records of precipitation amount and chemical properties (i.e., ion concentration, acidity, and conductance) at as many as 250 sites across the US. Rainfall is recorded to the nearest 0.01 inch with a weighingbucket rain gauge at each site. Chemical properties are analyzed at the Central Analytical Laboratory (NADP, 2015). Table 1 lists sites used in this study. We use monthly aggregate wet deposition of $\mathrm{NH}_{4}^{+}$and $\mathrm{NO}_{3}^{-}$for select sites. However, no data are available for SQ in JJA. For GT, we use the average of Yellowstone and Pinedale, WY, measurements because there are no wet deposition measurements made in 2010 in GT. For RM, there are three collocated monitoring sites, and we use the average of them.

The Clean Air Status and Trends Network (CASTNET, http://epa.gov/castnet) measures ambient concentration of nitrogen and sulfur weekly at about 90 sites across the US and
Canada. More than 20 of these sites are within Class I areas. A 3-stage filter pack is used to measure nitrogen concentrations. Dry deposition flux is then calculated using the dry deposition velocity estimated by the Multi-Layer Model (MLM) (CASTNET, 2014). For simplicity when discussing these values along with other observations, we refer to these derived quantities as dry deposition measurements, although we recognize here that dry deposition is not directly measured. We use monthly aggregate dry deposition of $\mathrm{NH}_{4}^{+}$, $\mathrm{NO}_{3}^{-}$, and $\mathrm{HNO}_{3}$ for select sites. Yellowstone and Pinedale, WY, measurements are used for GT since there is no CASTNET site in GT.

\subsection{GEOS-Chem model description}

GEOS-Chem (www.geos-chem.org) is a three-dimensional atmospheric CTM driven by meteorological input from the Goddard Earth Observing System (GEOS) of the NASA Global Modeling and Assimilation Office (Bey et al., 2001). We use GEOS-Chem adjoint version 35 with a nested grid resolution of $1 / 2^{\circ}$ latitude $\times 2 / 3^{\circ}$ longitude with 47 vertical layers up to $0.01 \mathrm{hPa}$ (Wang et al., 2004; Chen et al., 2009; Zhang et al., 2011) for the modeling domain over the contiguous US $\left(126-66^{\circ} \mathrm{W}, 13-57^{\circ} \mathrm{N}\right)$. The model includes detailed tropospheric gas-phase chemistry of the $\mathrm{O}_{3}-\mathrm{NO}_{x}$ hydrocarbon system (Hudman et al., 2007). Aerosols are assumed to be externally mixed and the thermodynamic equilibrium between gases and aerosol of $\mathrm{NH}_{3}-\mathrm{H}_{2} \mathrm{SO}_{4}-\mathrm{HNO}_{3}$ is calculated using RPMARES (Park et al., 2004). Wet deposition includes sub-grid scavenging in convective updrafts, large-scale in-cloud rainout, and below-cloud washout (Liu et al., 2001). Dry deposition is calculated using a resistancein-series model (Wesely, 1989; Wang et al., 1998). Resistances are aerodynamic resistance, quasi-laminar sublayer resistance, and bulk surface resistance. Bulk surface resistances are specified by different surface type, i.e., vegetation 


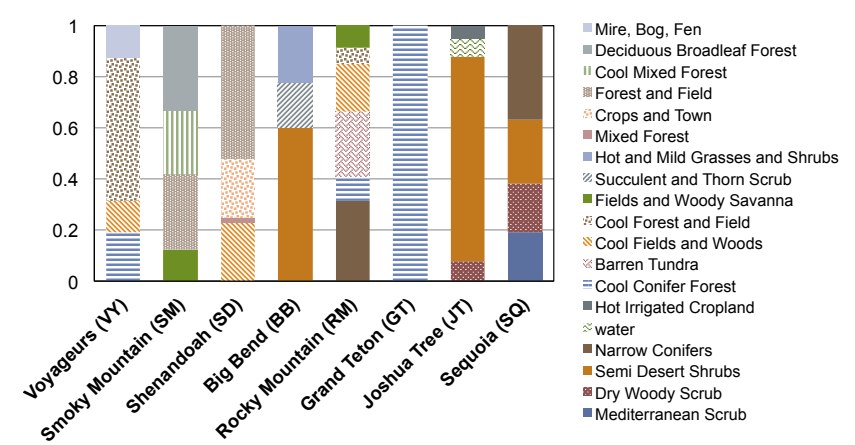

Figure 1. Composition of vegetation types of select Class I areas used in this study based on Olson (1992).

types (Wesely, 1989). We use vegetation types from Olson (1992), shown in Fig. 1.

Anthropogenic emissions of $\mathrm{NO}_{x}, \mathrm{SO}_{2}$, and $\mathrm{NH}_{3}$ in GEOS-Chem are taken from the National Emissions Inventory produced by the US EPA (EPA/NEI2008). Annual emissions of $\mathrm{NO}_{x}$ and $\mathrm{NH}_{3}$ in the contiguous US in 2010 are shown in Table 2. Mobile emissions of $\mathrm{NH}_{3}$ are not shown explicitly here, as they are $<4 \%$ of the US total in the NEI2008, although this may be an underestimate in urban areas (Kean et al., 2009). Anthropogenic sources of $\mathrm{NO}_{x}$ includes surface sources, electric generating units (EGUs), and non-EGU industrial point sources. Surface sources of $\mathrm{NO}_{x}$ comprises on-road (diesel and gasoline exhaust from cars and trucks, $68.4 \%$ ), non-road (off-road vehicles, construction equipment, industrial, commercial, and agricultural engines, $17.2 \%$ ), and non-point (not otherwise included, e.g., residential heating, oil and gas development, 14.4\%) sources. Biomass burning emissions are taken from the 3-h GFED3 inventory (Mu et al., 2011; van der Werf et al., 2010). $\mathrm{NO}_{x}$ emissions from aircraft are described in Wang et al. (1998). Natural emissions of $\mathrm{NO}_{x}$ are from lightning (Murray et al., 2012) and soil (Yienger and Levy, 1995; Wang et al., 1998). Natural emissions of $\mathrm{NH}_{3}$ from soil, vegetation, and ocean sources are from the GEIA inventory (Bouwman et al., 1997). In Sect. 3.3, we consider $\mathrm{NH}_{3}$ emissions constrained by remote-sensing observations from Zhu et al. (2013), which we refer to as optimized NEI2005. Bidirectional $\mathrm{NH}_{3}$ exchange is not considered in this study.

\section{3 $\mathrm{Nr}$ deposition metrics in Federal Class I areas}

Here we consider several metrics (cost functions) for quantifying $\mathrm{Nr}$ deposition and CL exceedances in Federal Class I areas. When considering strategies for reducing $\mathrm{Nr}$ deposition in Class I areas, several possible questions of interest arise, such as: (1) how do emissions from different source locations and sectors affect $\mathrm{Nr}$ deposition in specific individual Class I areas? (2) Which emissions contribute the most to the spatial extent of all Class I regions in exceedance? And (3) what is the amount by which emissions contribute
Table 2. $\mathrm{NO}_{x}$ and $\mathrm{NH}_{3}$ emissions in the contiguous US in 2010.

\begin{tabular}{lll}
\hline & Sectors & Emissions $\left(\mathrm{Tg} \mathrm{N} \mathrm{yr}^{-1}\right)$ \\
\hline $\mathrm{NH}_{3}$ & Total & 3.2 \\
& Livestock & 2.7 \\
& Fertilizer & 0.3 \\
& Natural & 0.1 \\
\hline $\mathrm{NO}_{x}$ & Total & 4.9 \\
& Surface & 2.6 \\
& EGUs ${ }^{\mathrm{a}}$ & 0.57 \\
& Non-EGU & 0.38 \\
& Aircraft & 0.13 \\
& Lightning & 0.69 \\
& Soil & 0.43 \\
\hline
\end{tabular}

${ }^{a}$ Electric generating units

to the severity of $\mathrm{Nr}$ deposition in Class I areas above CLs? Each of these three questions corresponds to a unique approach to defining the cost function for our sensitivity calculations. The cost functions in this study include the following constituents: the sum of wet and dry deposition of $\mathrm{NH}_{3}$, $\mathrm{NH}_{4}^{+}, \mathrm{NO}_{3}^{-}$, and $\mathrm{HNO}_{3}$, and dry deposition of $\mathrm{NO}_{2}$, PANs (peroxyacetyl nitrate and higher peroxyacyl nitrates: peroxymethacroyl nitrate, peroxypropionyl nitrate), alkyl nitrate, and $\mathrm{N}_{2} \mathrm{O}_{5}$. Although dry deposition of $\mathrm{NO}_{2}$, PANs, alkyl nitrate, and $\mathrm{N}_{2} \mathrm{O}_{5}$ are not part of the CL estimates by Pardo et al. (2011), the sum of these species does not significantly contribute to our modeled $\mathrm{Nr}$ deposition or comparison to these CLs.

We first consider a cost function formulated for source attribution of $\mathrm{Nr}$ deposition in an individual Class I area. It is defined as the annual $\mathrm{Nr}$ deposition in a region $\left[\mathrm{kg} \mathrm{Nha}^{-1} \mathrm{yr}^{-1}\right]$,

$J_{\mathrm{p}}=\sum_{i=1}^{N} \operatorname{annDep}_{i} \beta_{i}$,

where annDep $i$ is the annual $\mathrm{Nr}$ deposition in grid cell $i$, $\beta_{i}$ is the fraction of grid cell $i$ that is contained within the Class I area, and $N$ is the number of grid cells for which $\beta_{i}$ is nonzero for an individual Class I area. Sensitivities of this cost function provide a first order estimate of the contribution of emissions to annual $\mathrm{Nr}$ deposition in a particular Class I area.

We next consider a cost function that is the sum of $\mathrm{Nr}$ deposition in all Class I areas in CL exceedance, $J_{\mathrm{a}}$ $\left[\mathrm{kg} \mathrm{Nha}^{-1} \mathrm{yr}^{-1}\right]$, defined as

$J_{\mathrm{a}}=\sum_{i=1}^{L} \operatorname{annDep}_{i} \beta_{i}$,

where $L$ is the number of grid cells containing Federal Class I areas in which annual modeled $\mathrm{Nr}$ deposition has exceeded 
the $\mathrm{CL}$ values we use in this study and $\beta_{i}$ is the fraction of grid cell $i$ that is contained within each Class I area. This metric is proportional to the total area of Class I regions in CL exceedance. Sensitivities of $J_{\mathrm{a}}$ with respect to emissions thus identify which emissions contribute to the total spatial extent of Class I areas that have $\mathrm{Nr}$ deposition above their CL by any amount.

Lastly, we consider a third cost function that is the sum of square of the difference of annual $\mathrm{Nr}$ deposition and CL in all Class I areas in CL exceedance, $J_{\mathrm{c}}\left[\left(\mathrm{kg} \mathrm{Nha}^{-1} \mathrm{yr}^{-1}\right)^{2}\right]$, which defined as

$J_{\mathrm{c}}=0.5 \sum_{i=1}^{L}\left(\operatorname{annDep}_{i}-\mathrm{CL}_{i}\right)^{2} \beta_{i}$,

where $L$ and $\beta_{i}$ are same as Eq. (2) and $\mathrm{CL}_{i}$ is the critical load in grid cell $i$. While both Eqs. (2) and (3) include only regions where annual $\mathrm{Nr}$ deposition is higher than the CL, Eq. (3) is more strongly related to the magnitude of the $\mathrm{Nr}$ deposition in exceedance (the factor of 0.5 is habitually included for sensitivity calculations based on the first derivative of $J$ ). Sensitivities of $J_{\mathrm{c}}$ quantify the contribution of emissions to the magnitude of $\mathrm{Nr}$ deposition above CL loads, which can then guide analysis of mitigation efforts for reducing the most severe levels of $\mathrm{Nr}$ deposition.

\subsection{GEOS-Chem adjoint model}

The GEOS-Chem adjoint model (Henze et al., 2007) is a tool for receptor-based inverse modeling and sensitivity analysis (e.g., Kopacz et al., 2009; Wecht et al., 2012; Zhu et al., 2013). When it is used for a sensitivity analysis, gradients of the user defined cost function with respect to all model parameters are calculated simultaneously, making the model a very efficient tool for source attribution (e.g., Walker et al., 2012; Paulot et al., 2013; Lapina et al., 2014; Lee et al., 2014). Here we use the model to evaluate the sensitivity of $\mathrm{Nr}$ deposition to emission sources, including for the first time all chemical species of $\mathrm{Nr}$ present in the GEOS-Chem "full-chemistry" simulation, which considers $\mathrm{NO}_{x}-\mathrm{O}_{x}-\mathrm{HC}$ aerosol chemistry.

Non-normalized sensitivities quantify the change in the cost function per change in $\mathrm{kg}$ emission. We thus refer to this type of sensitivity as an efficiency in that large nonnormalized sensitivities indicate areas where reducing $\mathrm{Nr}$ emissions would have a very strong impact on $\mathrm{Nr}$ deposition in terms of the response of $\mathrm{Nr}$ deposition achieved per amount of emissions reduced (as opposed to locations where reducing emissions would have little effect on $\mathrm{Nr}$ deposition in the areas of interest, or locations where $\mathrm{Nr}$ emissions are just large in magnitude). These are defined as

$\lambda_{i, j} \equiv \frac{\partial J}{\partial E_{i, j}}$,

where $J$ is any of the cost functions defined in Sect. 2.3, and $\lambda_{i, j}$ is found from solution of the adjoint model. $E_{i, j}$ is the emission at grid cell $i$ of species $j$. Details of the adjoint model description and validation have been presented previously (Henze et al., 2007, 2009). We also consider the seminormalized sensitivity $\left[\mathrm{kg} \mathrm{Nha}^{-1} \mathrm{yr}^{-1}\right]$, defined as

$\chi_{i, j, k} \equiv \lambda_{i, j} \cdot E_{i, j, k}$,

where $E_{i, j, k}$ is the emission at grid cell $i$ of species $j$ from sector $k$. This sensitivity linearly approximates the contribution to the cost function of the emission in location $i$, of species $j$, from sector $k$. While the adjoint model computes sensitivities with respect to all emissions (e.g., $\mathrm{SO}_{2}$, VOCs, etc.), here we focus our analysis on sensitivities with respect to emissions of $\mathrm{NH}_{3}$ and $\mathrm{NO}_{x}$ from anthropogenic and natural sources, which are the largest. Sensitivity calculations are performed monthly, including a 1-week spin-up for each month to capture the influence of emissions from the end of the previous month.

\section{Results}

\subsection{Evaluation of simulated $\mathrm{Nr}$ deposition}

Figure 2 shows the spatial distribution of total, reduced, and oxidized annual $\mathrm{Nr}$ deposition in the contiguous US in 2010 calculated with GEOS-Chem. Total $\mathrm{Nr}$ deposition consists of all chemical species included in the cost function, reduced $\mathrm{Nr}$ deposition is the sum of wet and dry deposition of $\mathrm{NH}_{3}$ and $\mathrm{NH}_{4}^{+}$, and oxidized $\mathrm{Nr}$ deposition is total minus reduced. Total $\mathrm{Nr}$ deposition ranges from 2 to $5 \mathrm{~kg} \mathrm{Nha}^{-1} \mathrm{yr}^{-1}$ in the West, except in some parts of California where it is $>12 \mathrm{~kg} \mathrm{Nha}^{-1} \mathrm{yr}^{-1}$, and from 6 to $20 \mathrm{~kg} \mathrm{Nha}^{-1} \mathrm{yr}^{-1}$ in the East. Annual total $\mathrm{Nr}$ deposition over the contiguous US is $5.6 \mathrm{Tg} \mathrm{N}$ (3.2 oxidized, 2.4 reduced). Oxidized $\mathrm{Nr}$ is higher than reduced $\mathrm{Nr}$ overall, while reduced $\mathrm{Nr}$ is higher in midCalifornia, Iowa, and eastern North Carolina.

The spatial distribution of reduced and oxidized $\mathrm{Nr}$ deposition is comparable with other studies (Zhang et al., 2012; Du et al., 2014; Schwede and Lear, 2014) yet a few differences and uncertainties are worth considering. Du et al. (2014) found greater wet deposition of $\mathrm{NH}_{4}^{+}$compared to wet deposition of $\mathrm{NO}_{3}^{-}$over the contiguous US except in the Northeast region. The larger fraction of reduced wet $\mathrm{Nr}$ deposition in their work may be related to the year being analyzed (increased $\mathrm{NH}_{3}$ and decreased $\mathrm{NO}_{x}$ emissions in their study period of 2011-2012 compared to ours in 2010) and to the overestimation of $\mathrm{HNO}_{3}$ in our study that is discussed below.

Zhang et al. (2012), using the same model we use but with the different emissions, found that wet and dry $\mathrm{HNO}_{3}$ deposition is overestimated compared to observations when the model's isoprene nitrate is treated as $\mathrm{HNO}_{3}$, as in our simulation, rather than being treated separately as organic nitrate. Further, comparison of modeled to measured $\mathrm{HNO}_{3}$ deposition in Zhang et al. (2012) required consideration of 


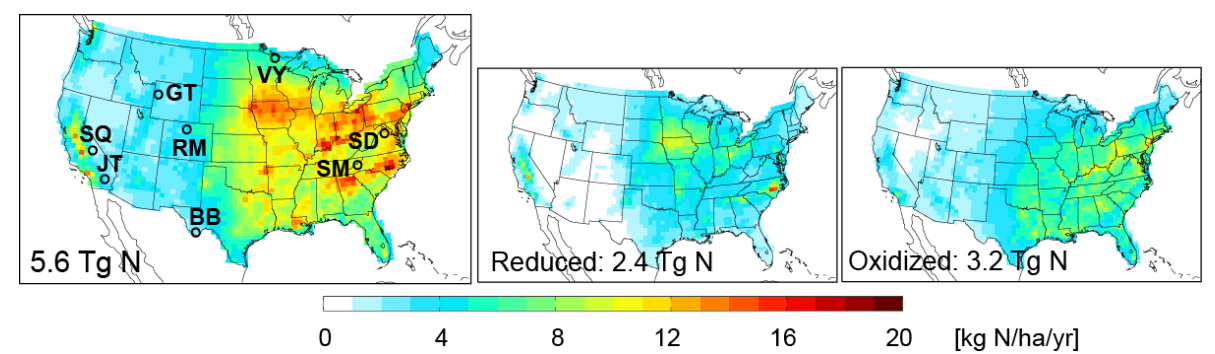

Figure 2. GEOS-Chem modeled Nr deposition in 2010. Select Class I areas for case studies are indicated by initials. Inset number is the annual contiguous US total $\mathrm{Nr}$ deposition.

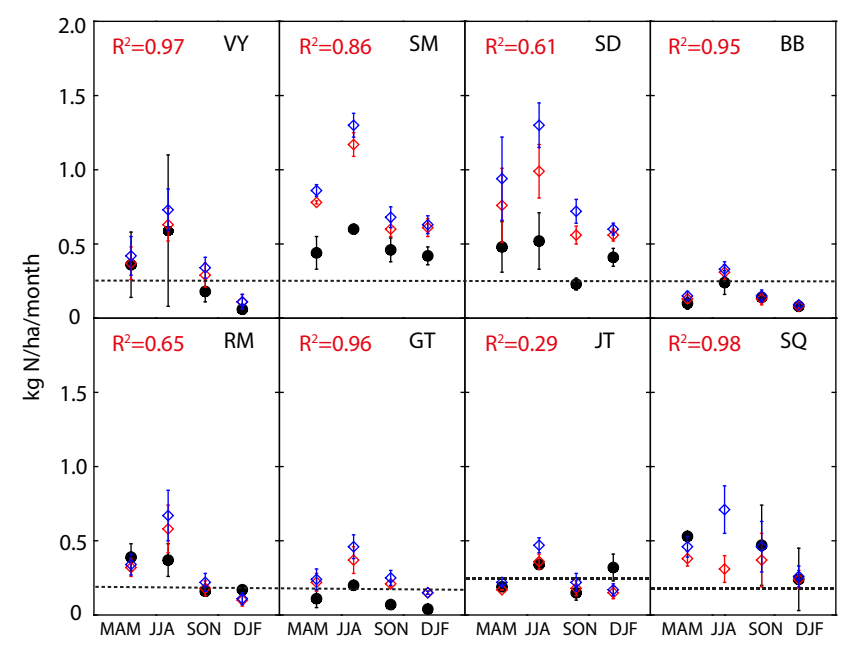

Figure 3. Seasonal variation of $\mathrm{Nr}$ deposition in select Class I areas. Model values (open red diamond) correspond to only those species that are measured (closed black circle). Cost function values $\left(J_{\mathrm{p}}\right.$, open blue diamond) also include dry deposition of $\mathrm{NH}_{3}, \mathrm{NO}_{2}$, PANs, alkyl nitrate, and $\mathrm{N}_{2} \mathrm{O}_{5}$. Bars indicate standard deviation of monthly averages in the season. $R^{2}$ is squared correlation coefficient for measured and modeled seasonal deposition. Dotted lines are for annual CLs divided by 12 in each site. MAM: March April May, JJA: June July August, SON: September October November, DJF: December January February.

sub-grid concentration gradients near the surface. Simulated ambient $\mathrm{HNO}_{3}$ concentrations are also overestimated (Heald et al., 2012), possibly owing to excessive $\mathrm{N}_{2} \mathrm{O}_{5}$ hydrolysis. This suggests that oxidized $\mathrm{Nr}$ may be overestimated in our study. Schwede and Lear (2014) generated maps of Nr deposition for multiple years, including 2010. These maps display localized hotspots in parts of Colorado and Idaho that are not evident in our results. The high $\mathrm{Nr}$ deposition in these regions is attributed to dry deposition of reduced nitrogen (Schwede and Lear, 2014), whereas in our result the contribution of reduced nitrogen deposition is generally less than that of oxidized nitrogen deposition (Fig. 2), possibly owing to the aforementioned overestimation of $\mathrm{HNO}_{3}$.

For the eight selected Class I areas, we compare seasonal average values from measurements provided by
NADP/NTN and CASTNET versus GEOS-Chem model estimates (Fig. 3). Total modeled $\mathrm{Nr}$ deposition in each Class I area ( $J_{\mathrm{p}}$, which includes non-measured species) is also plotted in Fig. 3 as blue diamonds to show the role of non-measured species. Seasonal averages are calculated from monthly values. Measured $\mathrm{Nr}$ corresponds to the sum of modeled wet deposition of $\mathrm{NH}_{3}, \mathrm{NH}_{4}^{+}, \mathrm{HNO}_{3}$, and $\mathrm{NO}_{3}^{-}$, and dry deposition of $\mathrm{NH}_{4}^{+}, \mathrm{NO}_{3}^{-}$, and $\mathrm{HNO}_{3}$. The squared correlation coefficient $\left(R^{2}\right)$ of measured and modeled $\mathrm{Nr}$ is shown in each plot. For SQ, $R^{2}$ is calculated with spring, fall, and winter data. The model well reproduces the seasonality of measurements $\left(R^{2}>0.6\right)$ except at JT. For all sites, measurements and model estimates have maximum values in the summer. Seasonally averaged measured $\mathrm{Nr}$ range from 0 to $0.6 \mathrm{~kg} \mathrm{Nha}^{-1}$ month $^{-1}$ (monthly value 0 to $1.3 \mathrm{~kg} \mathrm{Nha}^{-1}$ month $^{-1}$ ), modeled $\mathrm{Nr}$ range from 0.0 to $1.2 \mathrm{~kg} \mathrm{Nha}^{-1}$ month $^{-1}$ (monthly value 0 to $1.3 \mathrm{~kg} \mathrm{Nha}^{-1}$ month $^{-1}$ ) and $J_{\mathrm{p}}$ (modeled Nr including nonmeasured species) range from 0.1 to $1.3 \mathrm{~kg} \mathrm{Nha}^{-1}$ month $^{-1}$ (monthly value 0 to $1.4 \mathrm{~kg} \mathrm{Nha}^{-1}$ month $^{-1}$ ). Modeled Nr deposition is also higher than the measured $\mathrm{Nr}$ in the spring and summer in SM and SD, likely owing to overestimated $\mathrm{HNO}_{3}$ as discussed above. Additionally, our model grid-cell size $\left(\sim 3350 \mathrm{~km}^{2}\right)$ is larger than the largest Class I area (BB, $2866 \mathrm{~km}^{2}$ ). Representational error may thus also contribute to the discrepancy between the model and the measurement for regions with large emissions within grid cells containing the Class I area (e.g., SM and SD). Lastly, comparison to dry deposition measurements warrants some additional considerations. The MLM model used for deriving the CASTNET dry deposition values is subject to uncertainty in estimating dry deposition velocities (Schwede et al., 2011) because of a height-dependent non-physical component that can lead to an overestimation of $\mathrm{HNO}_{3}$ deposition by $10-30 \%$ (Saylor et al., 2014). Additionally, Hicks (2006) found that measurements of $\mathrm{HNO}_{3}$ dry deposition in a clearing, such as the CASTNET sites in SM and SD from which dry deposition measurements are derived, are lower than measurements of dry deposition to the surrounding forest canopy. Thus, measured $\mathrm{Nr}$ deposition in Class I areas that have large forested 


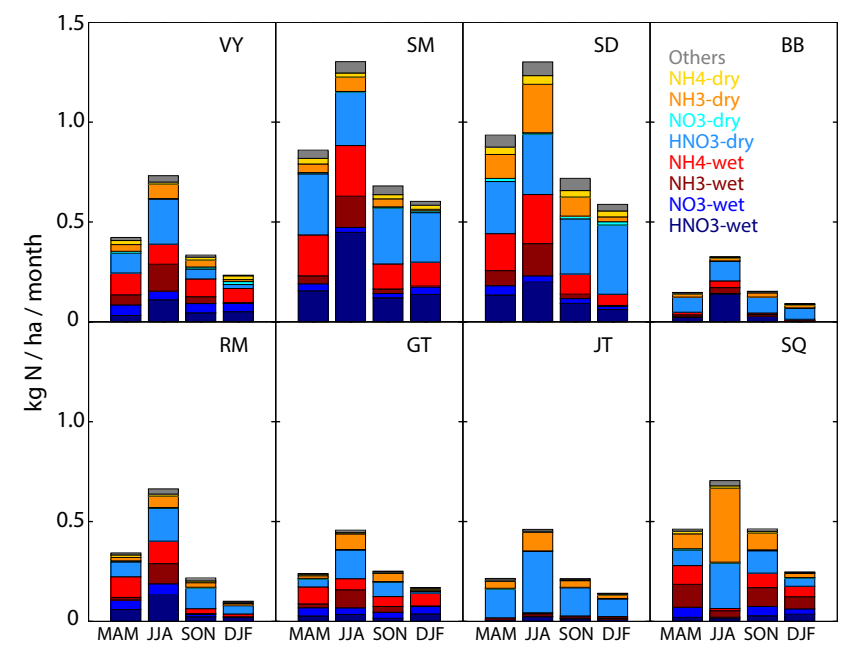

Figure 4. Stacked bar of modeled seasonal $\mathrm{Nr}$ deposition showing speciation. Others includes dry deposition of $\mathrm{NO}_{2}$, PANs, alkyl nitrate, and $\mathrm{N}_{2} \mathrm{O}_{5}$. Blueish: oxidized $\mathrm{N}$, reddish: reduced $\mathrm{N}$, dark: wet deposition, light: dry deposition.

areas (such as SM, SD, RM, GT, and SQ, see Fig. 1) is likely underestimated.

Annual modeled $\mathrm{Nr}$ deposition in each Class I area $\left(J_{\mathrm{p}}\right)$ ranges from 2.2 to $10.7 \mathrm{~kg} \mathrm{Nha}^{-1} \mathrm{yr}^{-1}$, and is highest in $\mathrm{SD}$ and SM and lowest in BB. The dotted lines in Fig. 3 show the annual CLs from Ellis et al. (2013) divided by 12. Class I areas considered to be in CL exceedance on an annual basis based on simulated values are VY, SM, SD, RM, GT, and SQ and those in exceedance based on measurement are VY, SM, $\mathrm{SD}, \mathrm{RM}$, and SQ. Within California, annual $\mathrm{Nr}$ deposition in SQ is about $70 \%$ larger than that in JT. This is influenced by the position of these parks relative to large upwind anthropogenic sources, as well as different vegetation types of the two parks (Fig. 1). JT is $80 \%$ desert where very low $\mathrm{Nr}$ deposition is expected; in contrast, SQ has narrow conifers and mediterranean scrub. The lowest annual $\mathrm{Nr}$ deposition in $\mathrm{BB}$ is explained, in part, by the large fraction of desert $(60 \%)$ and succulent and thorn scrub (18\%); it is also far from large anthropogenic sources.

Figure 4 shows the model speciation of $J_{\mathrm{p}}$. Non-measured species are dry deposition of $\mathrm{NO}_{2}$, PANs, alkyl nitrate, $\mathrm{N}_{2} \mathrm{O}_{5}$ (lumped as others in Fig. 4) and dry $\mathrm{NH}_{3}$. Non-measured species account for $0.5 \%$ (winter, SM) to $55.6 \%$ (summer, $\mathrm{SQ}$ ) of seasonally averaged $J_{\mathrm{p}}$ values in the model. Dry deposition of $\mathrm{NH}_{3}$ accounts for $14 \%$ of contiguous US total annual $\mathrm{Nr}$ deposition. The summer maximum of $J_{\mathrm{p}}$ is mainly driven by wet deposition of $\mathrm{HNO}_{3}$ (VY, SM, SD, BB, RM) and dry deposition of $\mathrm{HNO}_{3}$ (VY, GT, JT, SQ). Dry deposition of $\mathrm{NH}_{3}$ is a major contributor in SQ. Organics (PANs and alkyl nitrate) make only a small contribution $(<5 \%)$ to $\mathrm{Nr}$ deposition in the model. While it is known that organics account for $\sim 30 \%$ of total $\mathrm{Nr}$ deposition (Neff et al., 2002; Cornell, 2011), we expect organics to be underestimated in our model because only dry deposition is included for these species and isoprene nitrate is not explicitly treated (Zhang et al., 2012).

\subsection{Source attribution using GEOS-Chem adjoint}

\subsubsection{Spatial and sectoral footprints of $\mathrm{Nr}$ deposition}

The sensitivity of total annual $\mathrm{Nr}$ deposition $\left(J_{\mathrm{p}}\right)$ to emission sources is calculated by the GEOS-Chem adjoint model. The results can be understood as the contribution of emissions in each grid cell to the $\mathrm{Nr}$ deposition in each Class I area. Figure 5 shows spatial distributions of the sensitivities of $\mathrm{Nr}$ deposition to $\mathrm{NO}_{x}$ and $\mathrm{NH}_{3}$ emissions - the so called source footprint (Eq. 5) - for each region. Inset numbers are the annual $\mathrm{Nr}$ deposition in each area from all sources $\left(J_{\mathrm{p}}\right)$. Pie charts show the relative contributions to this value from specific emission sectors (sectors contributing $<1 \%$ are not shown).

The source attribution results show significant variability in terms of the sectors contributing to $\mathrm{Nr}$ deposition in different Class I areas. Livestock $\mathrm{NH}_{3}$ and surface source $\mathrm{NO}_{x}$, i.e., mobile sources, are the major sources of $\mathrm{Nr}$ deposition, contributing more than $65 \%$ to SM, SD, RM, GT, JT, and SQ. Livestock $\mathrm{NH}_{3}$ contributions are largest for SQ (54\%) and smallest for $\mathrm{BB}(15 \%)$. Mobile $\mathrm{NO}_{x}$ is the major emission source for JT (63\%), SM (40\%) and SD (38\%). Fertilizer $\mathrm{NH}_{3}$ is the third most important source of $\mathrm{Nr}$ deposition for VY $(14 \%)$, GT (11\%), and SQ (8\%). In contrast to the other sites, for $\mathrm{BB}$ the contribution of natural sources of $\mathrm{Nr}$ (the sum of natural $\mathrm{NH}_{3}$, lightning and soil $\mathrm{NO}_{x}$ equal to $47 \%$ ) is comparable to that of anthropogenic contributions. $\mathrm{NO}_{x}$ from EGUs is the third most important source for RM $(12 \%)$ and SD (9\%). Lightning is a considerable source not only for BB but for SM $(9 \%)$. Aircraft emissions have a noticeable impact only for JT ( $2 \%)$.

The results of the adjoint sensitivity calculations show that the spatial footprint of emissions affecting different Class I regions can vary by several hundred kilometers. Even though $\mathrm{NO}_{x}$ and $\mathrm{NH}_{3}$, by themselves, have very short lifetimes $(<1$ day), in the form of aerosol species they can influence $\mathrm{Nr}$ deposition over quite large distances, which is reflected in the maps in Fig. 5. To provide a quantitative means of evaluating the spatial extent of the footprint for each region, Fig. 6 shows cumulative contributions of annual average monthly $\mathrm{Nr}$ deposition by radial distance from each site. Blue and red lines indicate distances for which the cumulative influence is 50 and $90 \%$ of the total, respectively. For reference, the greatest distance within the contiguous US, from Florida to Washington, is about $4500 \mathrm{~km}$. It can be inferred from the shape of the plot that VY, SM, and BB have broad source regions spreading $\sim 1500 \mathrm{~km}$ from the site. In contrast, JT and SQ are mostly (90\%) influenced by sources within $700 \mathrm{~km}(\mathrm{JT})$ and $400 \mathrm{~km}$ (SQ). Local sources (within $50 \mathrm{~km}$ ) contribute more than $20 \%$ of total $\mathrm{Nr}$ deposition 
NH3(ls) NH3(fe) NH3(na) NOx(sf) NOx(eg) NOx(ne) NOx(ac) NOx(li) NOx(so)

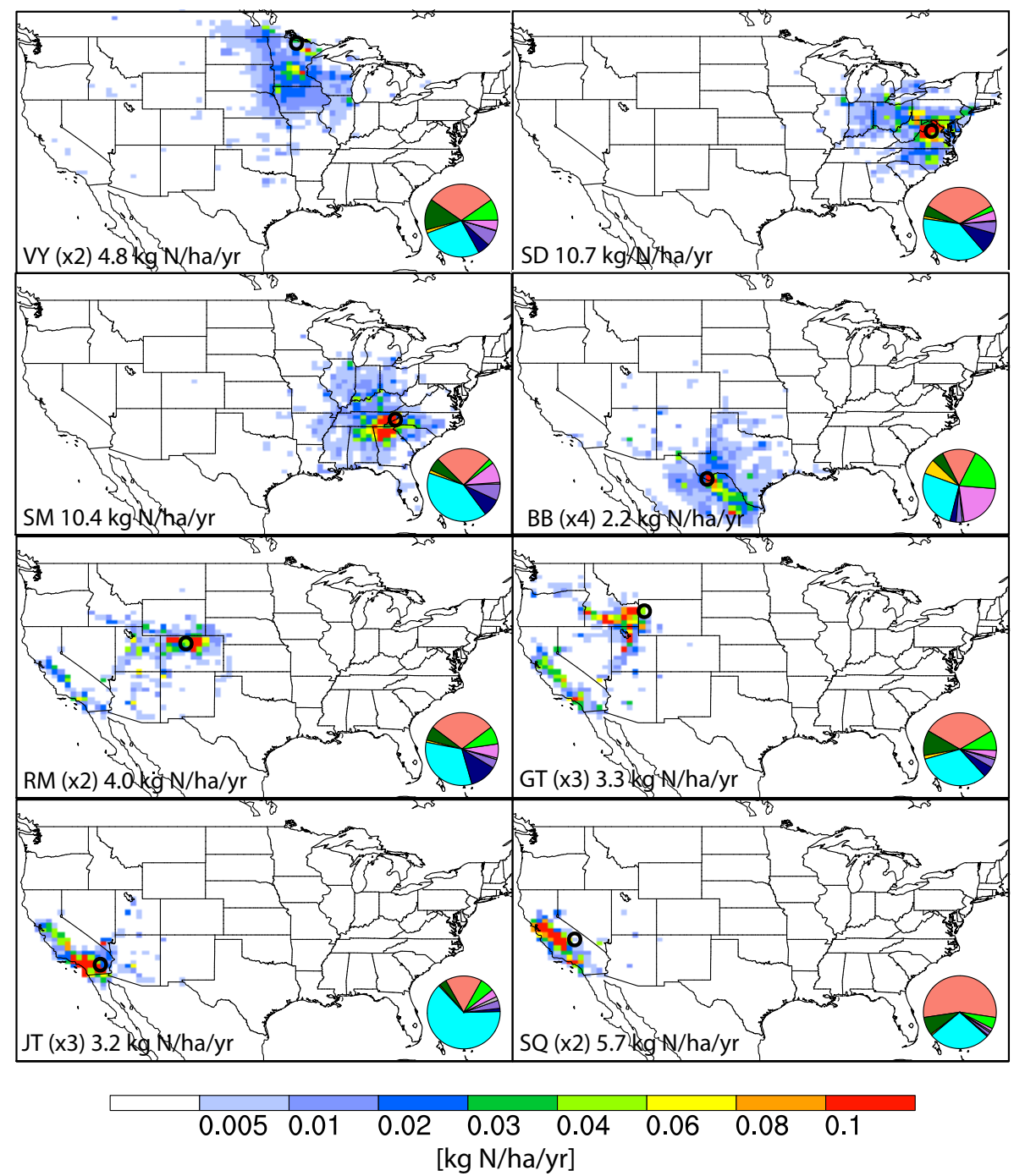

Figure 5. Annual-averaged monthly footprint $(\chi)$ of $\mathrm{Nr}$ deposition in each Class I area and pie chart of fractional contribution from emission sectors. ls: livestock, fe: fertilizer, na: natural, sf: surface inventory, eg: electric generating units, ne: non-eg industrial stacks, ac: aircraft, li: lightning, so: soil. Inset numbers are cost function $\left(J_{\mathrm{p}}\right)$, annual $\mathrm{Nr}$ deposition in each Class I area. Site locations are shown with open circles. Footprint values are scaled for visibility with numbers in parenthesis.

for $\mathrm{SD}$, while the rest are from more distant regions spread across $\sim 1100 \mathrm{~km}$. For RM and GT, there is a jump in the cumulative distribution around $1200 \mathrm{~km}$ which is due to sources in California. Steep initial rises for JT and SQ correspond to the influence of local urban centers (Los Angeles and San Francisco, respectively).

Additional analysis was performed for RM, given the prevalence of studies on $\mathrm{Nr}$ deposition in this area (Benedict et al., 2013b; Malm et al., 2013; Thompson et al., 2015). Figure 7 shows the source distributions of oxidized and reduced $\mathrm{Nr}$ deposition. Our results suggest that reduced $\mathrm{Nr}$ deposition originates primarily from east of the park, while in contrast a large fraction of oxidized $\mathrm{Nr}$ deposition originates from west of that park. This is consistent with the spatial distributions of the emissions of $\mathrm{NH}_{3}$ compared to those of $\mathrm{NO}_{x}$ surrounding the park. The high sensitivity of reduced $\mathrm{Nr}$ to sources west of RM in California and Idaho agrees with other recent studies (Benedict et al., 2013b; Malm et al., 2013; Thompson et al., 2015).

\subsubsection{Efficiency of emission impacts on $\mathrm{Nr}$ deposition}

For each Class I area, we also calculate non-normalized adjoint sensitivities as defined in Eq. (4) using the cost function defined in Eq. (1). These provide estimates of the response of $\mathrm{Nr}$ deposition $\left(J_{\mathrm{p}}\right)$ in each park per $\mathrm{kg}$ emissions of $\mathrm{NH}_{3}-$ $\mathrm{N}, \mathrm{NO}_{x}-\mathrm{N}$, and $\mathrm{SO}_{2}-\mathrm{S}$ in each month. These are a measure 


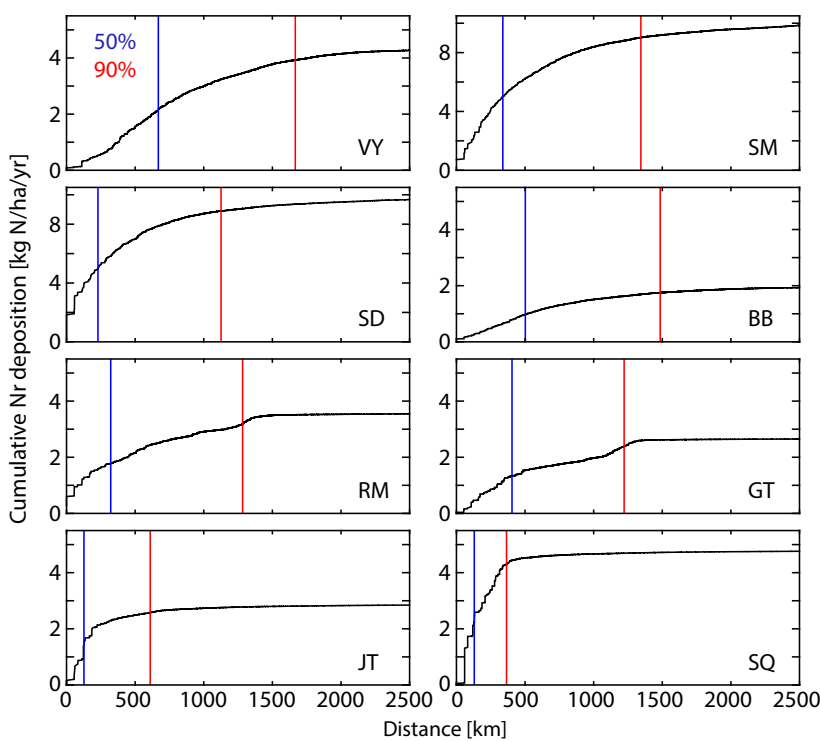

Figure 6. Annual averaged monthly cumulative contribution as a function of distance from the site. Vertical lines are for $50 \%$ (blue) and $90 \%$ (red) of total $\mathrm{Nr}$ deposition. Note the change in scale of the $y$ axis for SM and SD.

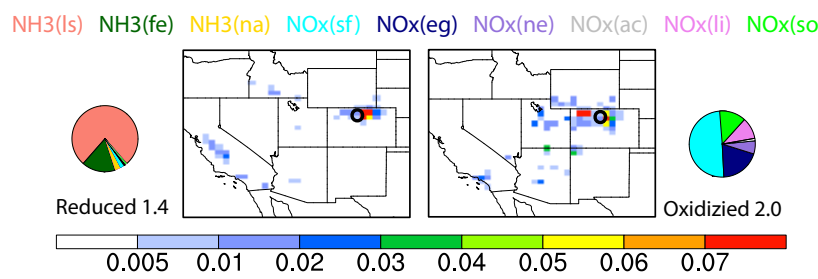

Figure 7. Same as Fig. 5 but for oxidized and reduce $\mathrm{Nr}$ deposition in RM. Units for the pie charts and colorbar are $\mathrm{kg} \mathrm{Nha}^{-1} \mathrm{yr}^{-1}$. The sum of the oxidized and reduced $\mathrm{Nr}$ deposition is smaller than the inset number in Fig. 5 because the number here excludes $\mathrm{Nr}$ from "other species".

of transport efficiency of each species, largely determined by meteorology and aerosol partitioning. Figure 8 shows a few select results with unique seasonal features in JJA and DJF.

In JT, there is a clear seasonal trend (Fig. 8a). Nr deposition in the park is impacted most efficiently by sources in the NW-SE direction during the summer and by sources in the NE-SW direction in the winter, due to changes in wind patterns. In RM, Nr deposition is owing to the sources from California during the summer, whereas the source footprints are much more localized during the winter (Fig. 8b). While stronger winds $\left(\geq 6 \mathrm{~m} \mathrm{~s}^{-1}\right)$ are actually more frequent in the winter, larger $\mathrm{NH}_{3}$ emissions in the summer facilitate formation of $\mathrm{NH}_{4} \mathrm{NO}_{3}$ and thus long-range $\mathrm{Nr}$ transport. In SD, $\mathrm{NH}_{3}$ emissions make a positive contribution to $\mathrm{Nr}$ deposition during the summer, while emissions north of the park contribute negatively during the winter (Fig. 8c). These negative sensitivities occur because $\mathrm{NH}_{4} \mathrm{NO}_{3}$ formation is limited by

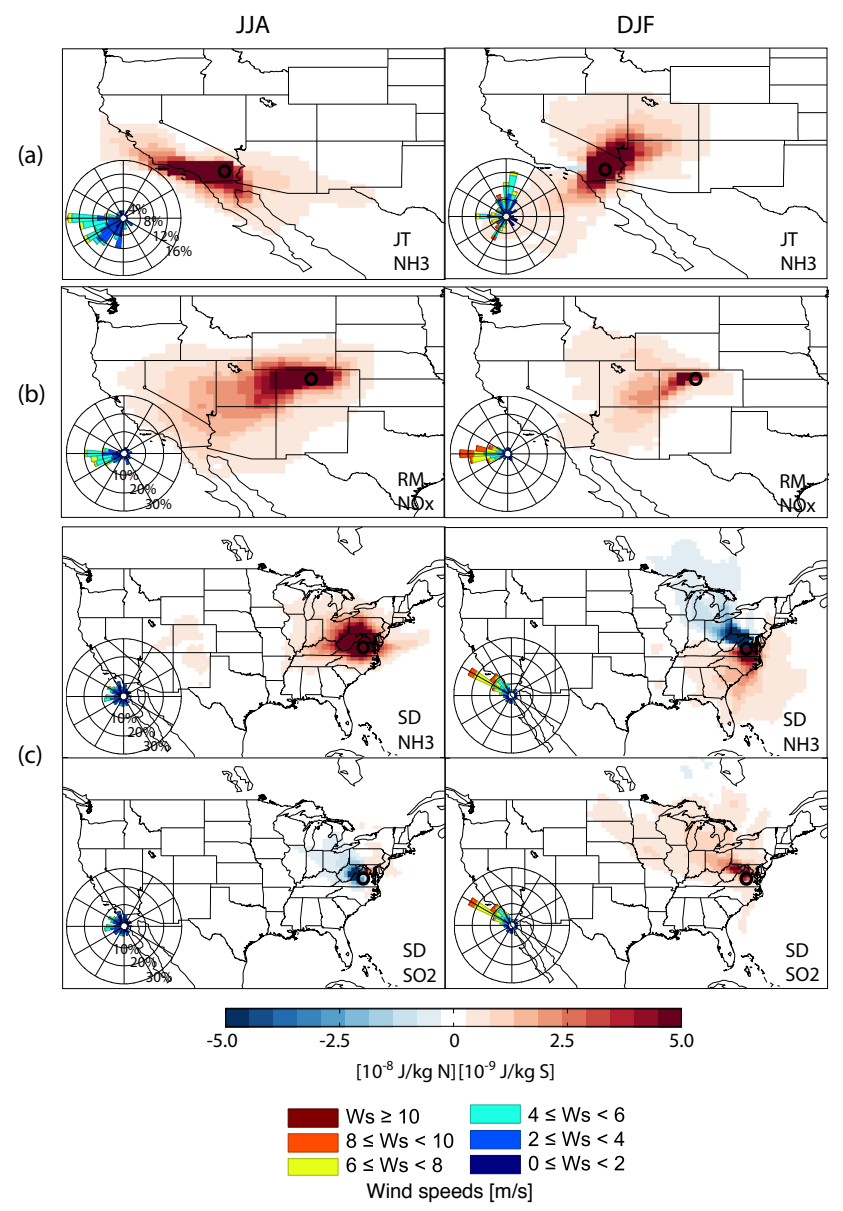

Figure 8. Efficiencies of impacts on $\mathrm{Nr}$ deposition showing cost function $\left(J_{\mathrm{p}}\right)$ change per $\mathrm{kg} \mathrm{N}$ or $\mathrm{kg} \mathrm{S}$ emission for the tracer and season indicated in the plot. (a) Joshua Tree, (b) Rocky Mountain, (c) Shenandoah national parks. Wind-roses for each site show fraction of wind frequencies based on daily surface winds during the season.

$\mathrm{NH}_{3}$ in the winter in SD. In these conditions, emissions of $\mathrm{NH}_{3}$ promote formation of $\mathrm{NH}_{4} \mathrm{NO}_{3}$. Since $\mathrm{NH}_{4} \mathrm{NO}_{3}$ has a longer lifetime in the atmosphere than gas-phase $\mathrm{NH}_{3}$ or $\mathrm{HNO}_{3}$, formation of $\mathrm{NH}_{4} \mathrm{NO}_{3}$ causes $\mathrm{Nr}$ to be transported further away, and thus less $\mathrm{Nr}$ deposits in the park. Thus, the deposition of $\mathrm{Nr}$ in the park has a negative sensitivity with respect to $\mathrm{NH}_{3}$ emissions. This tradeoff is also manifested by $\mathrm{SO}_{2}$ emissions having positive sensitivities during winter and negative sensitivities during summer. $\mathrm{In} \mathrm{NH}_{3}$ limited conditions (winter), increased $\mathrm{SO}_{2}$ emissions would tie up $\mathrm{NH}_{3}$ as aerosol $\left(\mathrm{NH}_{4}\right)_{2} \mathrm{SO}_{4}$ or $\mathrm{NH}_{4} \mathrm{HSO}_{4}$, leaving less $\mathrm{NH}_{3}$ available to form $\mathrm{NH}_{4} \mathrm{NO}_{3}$.

\subsubsection{Analysis of all Class I areas in critical load exceedance}

CL exceedance in Class I areas are shown in Fig. 9. In order to see the number of grid cells in CL exceedance, the 


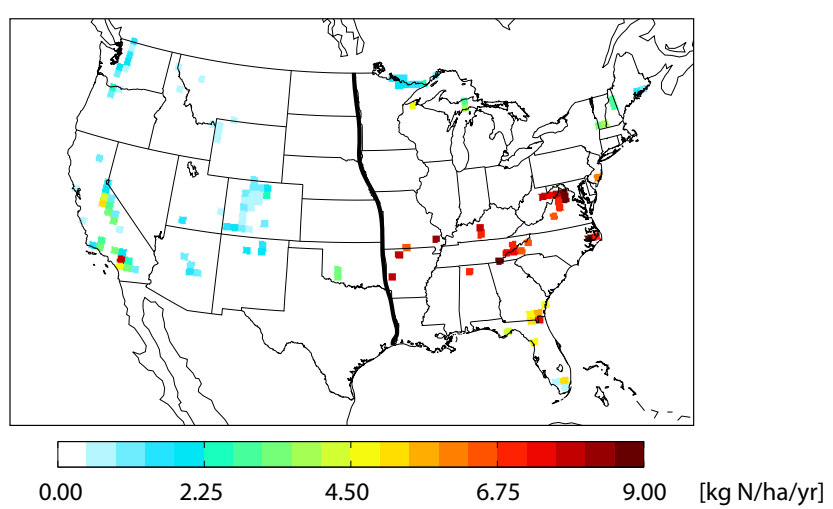

Figure 9. CL exceedance in Class I areas; color indicates magnitude of exceedance. The size of Class I areas is not reflected. Grid cells containing Class I areas are shown as colored regardless of the fraction of Class I areas. Bold line divides Western and Eastern US.

area of the regions is not reflected in this map; it are shown as filled cells if the fraction that the region occupies in the cell is greater than zero (although fractional grid cell areas, $\beta_{i}$, are considered in the model simulations themselves). The West/East contrast is clear. The number of cells in CL exceedance is larger in the West while the magnitude of the CL exceedance is larger in the East. This is not surprising considering the spatial distribution of $\mathrm{Nr}$ deposition (Fig. 2) and Class I areas. Among the 149 Class I areas in the contiguous US only 38 are located in the East. Figure 10a shows the sensitivity of $J_{\mathrm{a}}$ to $\mathrm{NO}_{x}$ and $\mathrm{NH}_{3}$ emissions. This sensitivity indicates the regions where reducing emission will result in the largest decrease in the extent of Class I areas in CL exceedance. Figure $10 \mathrm{~b}$ is the sensitivity of $J_{\mathrm{c}}$ to emissions. This sensitivity shows the sources that are causing the largest values of $\mathrm{Nr}$ deposition, relative to the CLs (i.e., excessive or severe values).

Comparison of the two types of sensitivity analysis suggests how different emission control strategies might be considered to meet different objectives. Decreasing $\mathrm{Nr}$ emissions in California and regions surrounding RM and SM would be useful for reducing both the extent of Class I areas in CL exceedance (Fig. 10a) and the amount of excessive Nr in Class I areas (Fig. 10b).

$\mathrm{Nr}$ originating from Idaho, Utah, Washington, and Arizona contribute more to reduce the extent of Class I areas in CL exceedance but less to the amount of excessive $\mathrm{Nr}$ in Class I areas, as the $\mathrm{Nr}$ deposition in these regions is not as excessive as it is in other regions, as shown in Fig. 9. Reducing $\mathrm{Nr}$ emissions from the tip of Florida would reduce the area of regions in CL exceedance, while reductions to emissions in this area are not as beneficial for avoiding excessively high deposition, as this region has the highest CL $\left(5 \mathrm{~kg} \mathrm{Nha}^{-1} \mathrm{yr}^{-1}\right)$ of those considered here. For reduction of excessive $\mathrm{Nr}$ above the CL, sources with the largest impact are located in the East (i.e., Tennessee, Alabama, and Georgia) and the San Joaquin

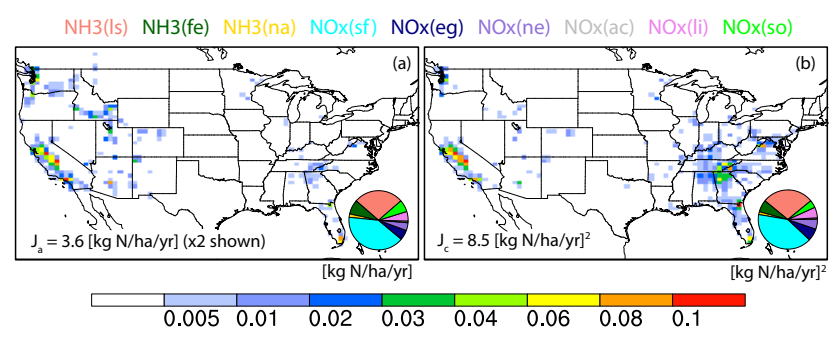

Figure 10. Same figure as Fig. 5 but with different cost functions. (a) $J_{\mathrm{a}}$, the sum of $\mathrm{Nr}$ deposition in all Class I areas in CL exceedance, (b) $J_{\mathrm{c}}$, the sum of square of the difference of annual $\mathrm{Nr}$ deposition and CL in all Class I areas in CL exceedance. Sensitivities of (a) are scaled by $\times 2$ to share the colorbar with (b).

Valley in California. Interestingly, the distribution of contributions across sectors is similar for both $J_{\mathrm{a}}$ and $J_{\mathrm{c}}$; surface $\mathrm{NO}_{x}$ and livestock $\mathrm{NH}_{3}$ are the major emission sectors contributing to both the extent and severity of CL exceedances.

\subsection{Uncertainty caused by $\mathrm{NH}_{3}$ emissions}

To evaluate the robustness of our source attribution analysis with respect to $\mathrm{NH}_{3}$ emissions uncertainties we compare our base case results using NEI2008 emissions to sensitivity results using NEI2005 $\mathrm{NH}_{3}$ emissions optimized using remote-sensing observations (Shephard et al., 2011) from Zhu et al. (2013). This is of interest not only because the magnitude of $\mathrm{NH}_{3}$ emissions may change the contribution of $\mathrm{NH}_{3}$ to $\mathrm{Nr}$ deposition, but also because $\mathrm{Nr}$ deposition is sensitive to long-range transport of ammonium and nitrate aerosol and $\mathrm{NH}_{3}$ abundance exerts a strong, nonlinear, influence on nitrate partitioning. As shown in Zhu et al. (2013), in the optimized NEI2005 the overall $\mathrm{NH}_{3}$ emissions have increased compared to the original NEI2005 inventory; emissions in California, the central US, and the Midwest are especially enhanced. Figure 11 shows the $\mathrm{NH}_{3}$ emissions from the optimized NEI2005 and those used in this study, NEI2008. The NEI2008 inventory has even larger $\mathrm{NH}_{3}$ emissions over the Midwest compared to the optimized NEI2005 in all 3 months shown here. In July, $\mathrm{NH}_{3}$ emissions in the central US (Kansas, Nebraska, eastern Colorado, and Texas) and Washington are higher with the optimized NEI2005.

Case studies are performed for VY, SD, and RM, whose $\mathrm{Nr}$ deposition footprint (Fig. 5) includes regions showing noticeable differences between the two $\mathrm{NH}_{3}$ emission inventories (Fig. 11). The non-normalized sensitivity, $\lambda_{i, j}$, remains constant with the changes in emissions but the seminormalized sensitivity, $\chi_{i, j, k}$, is perturbed by the differences in $E_{i, j, k}$. Figure 12 shows the sensitivities of $J_{\mathrm{p}}$ (total modeled $\mathrm{Nr}$ deposition in individual Class I areas) to $\mathrm{NH}_{3}$ emissions for these sites. Overall, when using NEI2008 the contribution of $\mathrm{NH}_{3}$ emissions to $J_{\mathrm{p}}$ is larger than when using the optimized NEI2005 inventory in all cases. Differences in $\mathrm{NH}_{3}$ emissions clearly affect sensitivities in VY. Differences 


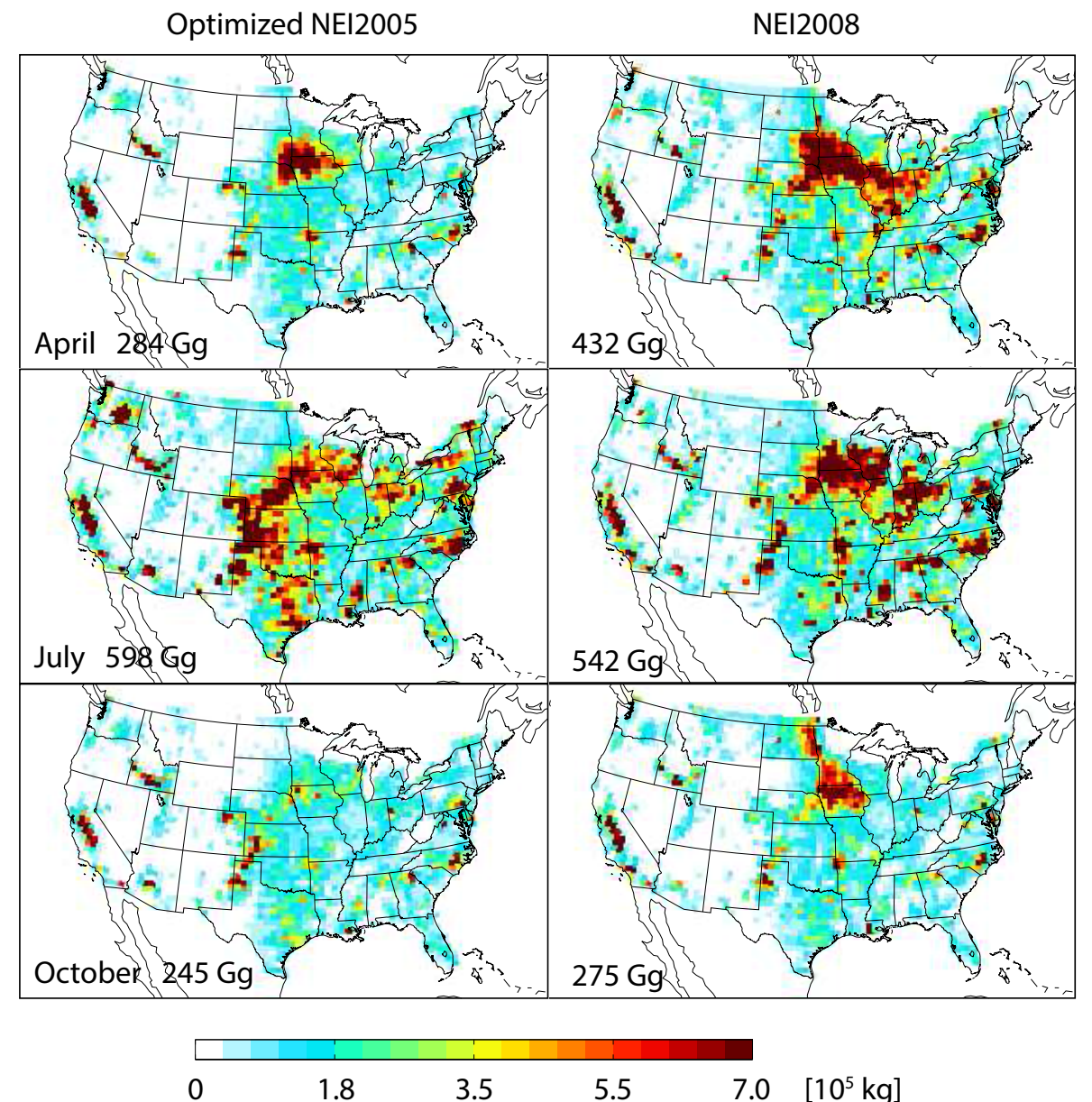

Figure 11. Sum of $\mathrm{NH}_{3}$ emissions from anthropogenic, natural, biomass burning, and biofuel sources. Inset numbers are contiguous US total $\mathrm{NH}_{3}$ emissions in each month.

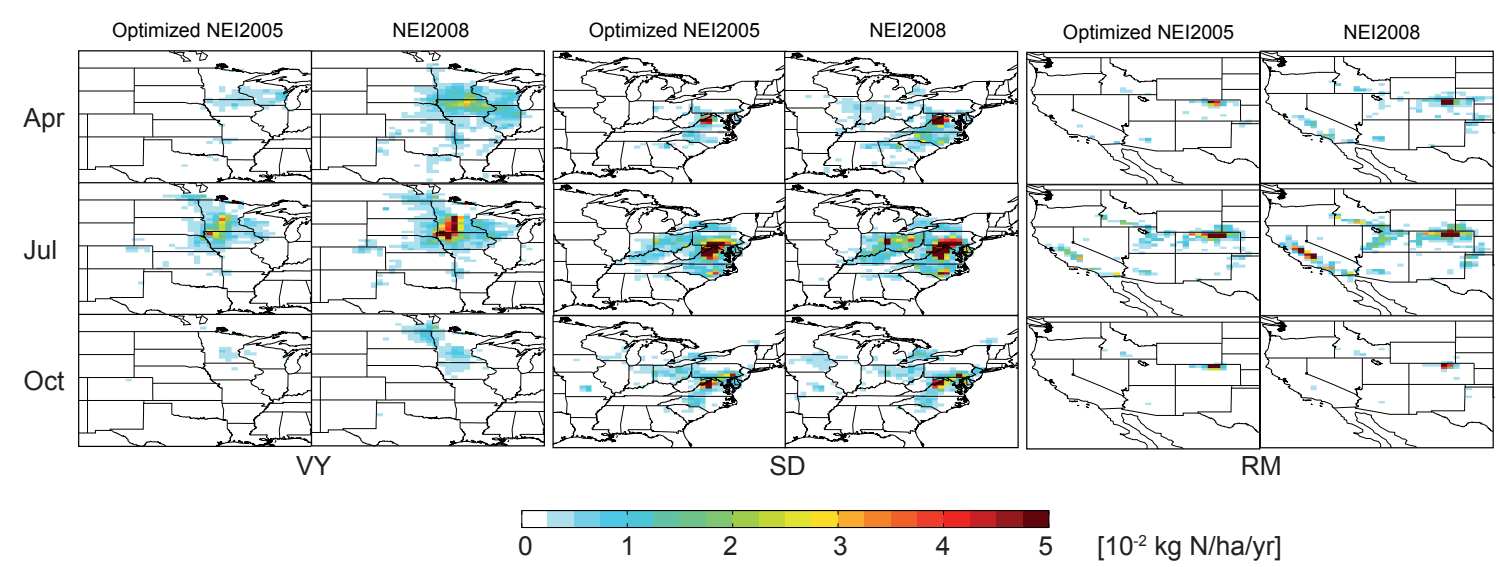

Figure 12. Map of sensitivities of $J_{\mathrm{p}}$ to $\mathrm{NH}_{3}$ emissions for three selected Class I areas (VY, SD, and $\mathrm{RM}$ ) for two different $\mathrm{NH}_{3}$ emission inventories (optimized NEI2005 and default NEI2008) in each month.

in emissions between the two inventories in Minnesota and Iowa mainly contribute to changes in the sensitivities for $\mathrm{Nr}$ deposition in VY. The source footprint for VY site gradually accumulates to $90 \%$ of the total $\mathrm{Nr}$ deposition at a distance of $1700 \mathrm{~km}$ from VY (see Figs. 5 and 6), which encompasses the regions in Iowa where the emissions have changed, which 
are $\sim 840 \mathrm{~km}$ away. SD is not affected much by different $\mathrm{NH}_{3}$ inventories in July and October as up to $50 \%$ of total $\mathrm{Nr}$ deposition is owing to sources within $250 \mathrm{~km}$ (Fig. 6). However, NEI2008 leads to broader estimates of the source footprints in April. Local influences become more pronounced for SD in the footprints estimated using the NEI2005 emissions. For the base case, $\mathrm{Nr}$ deposition was found to have significant long range influences for RM. However, when using the optimized NEI2005 emissions, where $\mathrm{NH}_{3}$ sources in eastern Colorado are estimated to be much larger, the relative role of long-range influence from east of the park is reduced.

\section{Discussion and conclusions}

We used the GEOS-Chem CTM and its adjoint model for $\mathrm{Nr}$ deposition source attribution in Federal Class I areas in the US. Among the eight selected Class I areas, Voyageurs, Smoky Mountain, Shenandoah, Rocky Mountain, Grand Teton, and Sequoia are estimated to be in exceedance of the most conservative estimates of CLs from Pardo et al. (2011). Modeled Nr deposition is compared with NADP/NTN (NADP, 2015) and CASTNET (CASTNET, 2014) measurements and other modeling studies (Zhang et al., 2012; Schwede and Lear, 2014). The seasonality of measured species is generally well represented by the model $\left(R^{2}>0.6\right)$, except in Joshua Tree. Modeled Nr deposition contains large contributions from wet $\mathrm{HNO}_{3}$ deposition which is likely overestimated in the version of the model used here (Zhang et al., 2012), leading to overestimates of $\mathrm{Nr}$ deposition in Smoky Mountain and Shenandoah of up to $0.6 \mathrm{~kg} \mathrm{Nha}^{-1}$ month $^{-1}$. Still, adequate model performance in other seasons and locations suggests a considerable contribution of dry deposition of $\mathrm{NH}_{3}$ in some locations and seasons, consistent with Schwede and Lear (2014). A significant fraction of $\mathrm{Nr}$ deposition in the central mountain region (including Rocky Mountain National Park) is estimated to be in the form of reduced nitrogen, similar to several other recent studies (Benedict et al., 2013b; Malm et al., 2013; Thompson et al., 2015), although such estimates are sensitive to model uncertainties in $\mathrm{NH}_{3}$ emissions and modeled $\mathrm{NO}_{3}^{-}$.

The spatial and sectoral distribution of annual $\mathrm{Nr}$ deposition sources are investigated using the adjoint of GEOSChem. Quantifying the contribution of local versus longrange transport and the contribution of different sectors to $\mathrm{Nr}$ deposition may serve as a guide for devising locally tailored strategies to reduce $\mathrm{Nr}$ deposition in different Class I areas. $\mathrm{NH}_{3}$ emissions from livestock and $\mathrm{NO}_{x}$ emissions from mobile sources are the major sectors that contribute to $\mathrm{Nr}$ deposition in all selected Class I areas, except Big Bend where natural sources contribute comparably with anthropogenic sources. Nr deposition in Joshua Tree and Sequoia, both located in California, tends to originate from local $(<$ $700 \mathrm{~km}$ ) sources, whereas $\mathrm{Nr}$ deposition in the mountain regions (Grand Teton and Rocky Mountain) are $\sim 50 \%$ from nearby sources $(<400 \mathrm{~km})$ and the rest from sources as far away as California $(\sim 1300 \mathrm{~km})$. For other parks (Voyageurs, Smoky Mountain, Shenandoah, and Big Bend), sources are broadly distributed radially. Overall, these results suggest that mitigating $\mathrm{Nr}$ deposition in many specific areas may require substantial consideration of interstate transport.

The efficiency of emissions to impact $\mathrm{Nr}$ deposition is evaluated at the per-kg emission level for $\mathrm{NH}_{3}-\mathrm{N}, \mathrm{NO}_{x}-\mathrm{N}$, and $\mathrm{SO}_{2}-\mathrm{S}$. This result represents the response of $\mathrm{Nr}$ deposition to additional emissions, which is useful for consideration of the impact of future emission. As it is expected (e.g., Ellis et al., 2013) that $\mathrm{NH}_{3}$ emissions will increase and $\mathrm{NO}_{x}$ emissions will decrease in the US in the coming decades, the formation of ammonium nitrate will increasingly be limited by $\mathrm{NO}_{x}$. This will cause the sensitivities of deposition that contains considerable contributions from ammonium nitrate, such as Voyageurs and Grand Teton national parks, to be increasingly sensitive to perturbations in $\mathrm{NO}_{x}$ emissions, even though $\mathrm{NH}_{3}$ emissions will make larger contributions to total $\mathrm{Nr}$ deposition. In Joshua Tree, $\mathrm{NH}_{3}$ emission efficiencies show distinct seasonality in terms of their locations. The NW-SE impact is strongest in summer and the NE-SW impact is dominant in winter. In Rocky Mountain, effective regions, where emissions from the region would contribute to more than $\sim \pm 1.0 \times 10^{-8} \mathrm{~kg} \mathrm{Nha}^{-1} \mathrm{yr}^{-1}$ per kg N emission or $\sim \pm 1.0 \times 10^{-9} \mathrm{~kg} \mathrm{Nha}^{-1} \mathrm{yr}^{-1}$ per kg S emission, are broader in the summer even though stronger winds are more frequent in the winter (Fig. 8), owing to larger $\mathrm{NH}_{3}$ sources in the summer. In Shenandoah, $\mathrm{NH}_{3}$ emissions to the north of the park inhibit $\mathrm{Nr}$ deposition in the park during the winter. This response is interesting, and explainable from consideration of aerosol partitioning and transport, although the absolute significance is not that large owing to the small levels of deposition here in the winter.

Sources of $\mathrm{Nr}$ deposition in all Class I areas in CL exceedance throughout the US are studied using two approaches: emissions contributing to the extent of the total area of Class I areas that are in CL exceedance $\left(J_{\mathrm{a}}\right)$ and emissions contributing to the magnitude of the excessive $\mathrm{Nr}$ deposition above CLs $\left(J_{\mathrm{c}}\right)$. Our result suggests that one of the largest source regions contributing to the spatial extent of Class I regions in CL exceedance is California. On the other hand, $\mathrm{Nr}$ sources in the Eastern US, i.e., Tennessee, Alabama, and Georgia, in addition to California, contribute the most to excessive $\mathrm{Nr}$ above the $\mathrm{CL}$ in Class I areas. Thus, strategies for reducing the spatial extent of ecological damage from excessive $\mathrm{Nr}$ deposition may differ from those aimed at reducing its severity.

Lastly, case studies are performed for Voyageurs, Shenandoah, and Rocky Mountain national parks using different $\mathrm{NH}_{3}$ emission inventories, which have large uncertainties, in order to evaluate how sensitive our source footprint estimates are to underlying model emissions. We adopted $\mathrm{NH}_{3}$ emissions optimized using remote-sensing observations (Zhu et al., 2013) to compare with our results using the NEI2008 
inventory, which has greater $\mathrm{NH}_{3}$ emissions in the Midwest and California. Difference in semi-normalized sensitivity is most apparent in April and July. Differences of $\mathrm{NH}_{3}$ emissions in Minnesota and Iowa are mainly reflected in the source footprint for Voyageurs. Estimated local influences become more important for Shenandoah when using the optimized NEI2005 inventory. For Rocky Mountain, when using the optimized NEI2005 emissions, $\mathrm{NH}_{3}$ sources in eastern Colorado are estimated to be much larger, but the role of long-range influences is reduced.

Overall, the results presented here provide useful information for considering how emissions control strategies both regionally and nationally may impact $\mathrm{Nr}$ deposition in Federal Class I areas. Future work may strive to apply such methods to higher resolution models, as model resolution may impact the ability to resolve fine-scale features delineating specific sources or areas of influence and complex topography in Class I areas. In addition, considering the role of bidirectional $\mathrm{NH}_{3}$ exchange (e.g., Zhu et al., 2015), which can effectively extend the source footprint owing to reemission of $\mathrm{NH}_{3}$ from $\mathrm{NH}_{3}$ rich soils, would be of interest. Lastly, as source attribution estimates for $\mathrm{Nr}$ deposition are intrinsically sensitive to uncertainties in the balance of emissions between $\mathrm{NH}_{3}$ and $\mathrm{NO}_{x}$, even if the total nitrogen emissions are correct, further effort should be made to improve knowledge of the distributions and trends in $\mathrm{NH}_{3}$ and $\mathrm{NO}_{x}$ emissions.

Acknowledgements. We acknowledge support from the NASA Air Quality Applied Sciences Team, grant NNX11AI54G and NSF grant ANT 1244958.

Edited by: R. Cohen

\section{References}

Bash, J. O., Cooter, E. J., Dennis, R. L., Walker, J. T., and Pleim, J. E.: Evaluation of a regional air-quality model with bidirectional $\mathrm{NH}_{3}$ exchange coupled to an agroecosystem model, Biogeosciences, 10, 1635-1645, doi:10.5194/bg-10-1635-2013, 2013.

Benedict, K. B., Chen, X., Sullivan, A. P., Li, Y., Day, D., Prenni, A. J., Levin, E. J. T., Kreidenweis, S. M., Malm, W. C., Schichtel, B. A., and Collett, J. L.: Atmospheric concentrations and deposition of reactive nitrogen in Grand Teton National Park, J. Geophys. Res.-Atmos., 118, 11875-11887, doi:10.1002/2013JD020394, 2013a.

Benedict, K. B., Day, D., Schwandner, F. M., Kreidenweis, S. M., Schichtel, B., Malm, W. C., and Collett Jr., J. L.: Observations of atmospheric reactive nitrogen species in Rocky Mountain National Park and across northern Colorado, Atmos. Environ., 64, 66-76, doi:10.1016/j.atmosenv.2012.08.066, 2013b.

Bey, I., Jacob, D. J., Yantosca, R. M., Logan, J. A., Field, B. D., Fiore, A. M., Li, Q., Liu, H. Y., Mickley, L. J., and Schultz, M. G.: Global modeling of tropospheric chemistry with assimilated meteorology: Model description and evaluation, J.
Geophys. Res., 106, 23073-23095, doi:10.1029/2001JD000807, 2001.

Bobbink, R., Hicks, K., Galloway, J., Spranger, T., Alkemade, R., Ashmore, M., Bustamante, M., Cinderby, S., Davidson, E., Dentener, F., Emmett, B., Erisman, J.-W., Fenn, M., Gilliam, F., Nordin, A., Pardo, L., and De Vries, W.: Global assessment of nitrogen deposition effects on terrestrial plant diversity: a synthesis, Ecol. Appl., 20, 30-59, doi:10.1890/08-1140.1, 2010.

Bouwman, A. F., Lee, D. S., Asman, W. a. H., Dentener, F. J., Van Der Hoek, K. W., and Olivier, J. G. J.: A global high-resolution emission inventory for ammonia, Global Biogeochem. Cy., 11, 561-587, doi:10.1029/97GB02266, 1997.

Bowman, W. D., Murgel, J., Blett, T., and Porter, E.: Nitrogen critical loads for alpine vegetation and soils in Rocky Mountain National Park, J. Environ. Manage., 103, 165-171, doi:10.1016/j.jenvman.2012.03.002, 2012.

CASTNET: U.S. Environmental Protection Agency Clean Air Markets Division Clean Air Status and Trends Network (CASTNET) Data table accessed (NH4, NO3, HNO3 Weekly Dry Deposition), available at: www.epa.gov/castnet, last access: 9 November 2014.

Chen, D., Wang, Y., McElroy, M. B., He, K., Yantosca, R. M., and Le Sager, P.: Regional CO pollution and export in China simulated by the high-resolution nested-grid GEOS-Chem model, Atmos. Chem. Phys., 9, 3825-3839, doi:10.5194/acp-9-3825-2009, 2009.

Clark, C. M., Morefield, P. E., Gilliam, F. S., and Pardo, L. H.: Estimated losses of plant biodiversity in the United States from historical N deposition (1985-2010), Ecology, 94, 1441-1448, doi:10.1890/12-2016.1, 2013.

Cooter, E. J., Bash, J. O., Walker, J. T., Jones, M. R., and Robarge, W.: Estimation of NH3 bi-directional flux from managed agricultural soils, Atmos. Environ., 44, 2107-2115, doi:10.1016/j.atmosenv.2010.02.044, 2010.

Cornell, S. E.: Atmospheric nitrogen deposition: Revisiting the question of the importance of the organic component, Environ. Pollut., 159, 2214-2222, doi:10.1016/j.envpol.2010.11.014, 2011.

Du, E., Vries, W. D., Galloway, J. N., Hu, X., and Fang, J.: Changes in wet nitrogen deposition in the United States between 1985 and 2012, Environ. Res. Lett., 9, 095004, doi:10.1088/17489326/9/9/095004, 2014.

Duce, R. A., LaRoche, J., Altieri, K., Arrigo, K. R., Baker, A. R., Capone, D. G., Cornell, S., Dentener, F., Galloway, J., Ganeshram, R. S., Geider, R. J., Jickells, T., Kuypers, M. M., Langlois, R., Liss, P. S., Liu, S. M., Middelburg, J. J., Moore, C. M., Nickovic, S., Oschlies, A., Pedersen, T., Prospero, J., Schlitzer, R., Seitzinger, S., Sorensen, L. L., Uematsu, M., Ulloa, O., Voss, M., Ward, B., and Zamora, L.: Impacts of Atmospheric Anthropogenic Nitrogen on the Open Ocean, Science, 320, 893897, doi:10.1126/science.1150369, 2008.

Ellis, R. A., Jacob, D. J., Sulprizio, M. P., Zhang, L., Holmes, C. D., Schichtel, B. A., Blett, T., Porter, E., Pardo, L. H., and Lynch, J. A.: Present and future nitrogen deposition to national parks in the United States: critical load exceedances, Atmos. Chem. Phys., 13, 9083-9095, doi:10.5194/acp-13-9083-2013, 2013.

Fenn, M. E., Baron, J. S., Allen, E. B., Rueth, H. M., Nydick, K. R., Geiser, L., Bowman, W. D., Sickman, J. O., Meixner, T., Johnson, D. W., and Neitlich, P.: 
Ecological Effects of Nitrogen Deposition in the Western United States, BioScience, 53, 404-420, doi:10.1641/00063568(2003)053[0404:EEONDI]2.0.CO;2, 2003.

Fenn, M. E., Allen, E. B., Weiss, S. B., Jovan, S., Geiser, L. H., Tonnesen, G. S., Johnson, R. F., Rao, L. E., Gimeno, B. S., Yuan, F., Meixner, T., and Bytnerowicz, A.: Nitrogen critical loads and management alternatives for $\mathrm{N}$-impacted ecosystems in California, J. Environ. Manage., 91, 2404-2423, doi:10.1016/j.jenvman.2010.07.034, 2010.

Galloway, J. N., Aber, J. D., Erisman, J. W., Seitzinger, S. P., Howarth, R. W., Cowling, E. B., and Cosby, B. J.: The nitrogen cascade, BioScience, 53, 341-356, doi:10.1641/00063568(2003)053[0341:TNC]2.0.CO;2, 2003.

Gilliland, A. B., Dennis, R. L., Roselle, S. J., and Pierce, T. E.: Seasonal NH3 emission estimates for the eastern United States based on ammonium wet concentrations and an inverse modeling method, J. Geophys. Res., 108, 4477, doi:10.1029/2002JD003063, 2003.

Gilliland, A. B., Wyat Appel, K., Pinder, R. W., and Dennis, R. L.: Seasonal NH3 emissions for the continental united states: Inverse model estimation and evaluation, Atmos. Environ., 40, 49864998, doi:10.1016/j.atmosenv.2005.12.066, 2006.

Gruber, N. and Galloway, J. N.: An Earth-system perspective of the global nitrogen cycle, Nature, 451, 293-296, doi:10.1038/nature06592, 2008.

Heald, C. L., Collett Jr., J. L., Lee, T., Benedict, K. B., Schwandner, F. M., Li, Y., Clarisse, L., Hurtmans, D. R., Van Damme, M., Clerbaux, C., Coheur, P.-F., Philip, S., Martin, R. V., and Pye, H. O. T.: Atmospheric ammonia and particulate inorganic nitrogen over the United States, Atmos. Chem. Phys., 12, 10295-10312, doi:10.5194/acp-12-10295-2012, 2012.

Henze, D. K., Hakami, A., and Seinfeld, J. H.: Development of the adjoint of GEOS-Chem, Atmos. Chem. Phys., 7, 2413-2433, doi:10.5194/acp-7-2413-2007, 2007.

Henze, D. K., Seinfeld, J. H., and Shindell, D. T.: Inverse modeling and mapping US air quality influences of inorganic $\mathrm{PM}_{2.5}$ precursor emissions using the adjoint of GEOS-Chem, Atmos. Chem. Phys., 9, 5877-5903, doi:10.5194/acp-9-5877-2009, 2009.

Hicks, B. B.: Dry deposition to forests - On the use of data from clearings, Agric. Forest Meteorol., 136, 214-221, doi:10.1016/j.agrformet.2004.06.013, 2006.

Hudman, R. C., Jacob, D. J., Turquety, S., Leibensperger, E. M., Murray, L. T., Wu, S., Gilliland, A. B., Avery, M., Bertram, T. H., Brune, W., Cohen, R. C., Dibb, J. E., Flocke, F. M., Fried, A., Holloway, J., Neuman, J. A., Orville, R., Perring, A., Ren, X., Sachse, G. W., Singh, H. B., Swanson, A., and Wooldridge, P. J.: Surface and lightning sources of nitrogen oxides over the United States: Magnitudes, chemical evolution, and outflow, J. Geophys. Res., 112, D12S05, doi:10.1029/2006JD007912, 2007.

Kean, A. J., Littlejohn, D., Ban-Weiss, G. A., Harley, R. A., Kirchstetter, T. W., and Lunden, M. M.: Trends in on-road vehicle emissions of ammonia, Atmos. Environ., 43, 1565-1570, doi:10.1016/j.atmosenv.2008.09.085, 2009.

Kopacz, M., Jacob, D. J., Henze, D. K., Heald, C. L., Streets, D. G., and Zhang, Q.: Comparison of adjoint and analytical Bayesian inversion methods for constraining Asian sources of carbon monoxide using satellite (MOPITT) mea- surements of CO columns, J. Geophys. Res., 114, D04305, doi:10.1029/2007JD009264, 2009.

Lapina, K., Henze, D. K., Milford, J. B., Huang, M., Lin, M., Fiore, A. M., Carmichael, G., Pfister, G. G., and Bowman, K.: Assessment of source contributions to seasonal vegetative exposure to ozone in the U.S., J. Geophys. Res.-Atmos., 119, 324-340, doi:10.1002/2013JD020905, 2014.

Lee, H.-M., Henze, D. K., Alexander, B., and Murray, L. T.: Investigating the sensitivity of surface-level nitrate seasonality in Antarctica to primary sources using a global model, Atmos. Environ., 89, 757-767, doi:10.1016/j.atmosenv.2014.03.003, 2014.

Liu, H., Jacob, D. J., Bey, I., and Yantosca, R. M.: Constraints from $210 \mathrm{~Pb}$ and $7 \mathrm{Be}$ on wet deposition and transport in a global threedimensional chemical tracer model driven by assimilated meteorological fields, J. Geophys. Res.-Atmos., 106, 12109-12128, doi:10.1029/2000JD900839, 2001.

Malm, W. C., Schichtel, B. A., Barna, M. G., Gebhart, K. A., Rodriguez, M. A., Jr, J. L. C., Carrico, C. M., Benedict, K. B., Prenni, A. J., and Kreidenweis, S. M.: Aerosol species concentrations and source apportionment of ammonia at Rocky Mountain National Park, J. Air Waste Manage., 63, 1245-1263, doi:10.1080/10962247.2013.804466, 2013.

Mu, M., Randerson, J. T., van der Werf, G. R., Giglio, L., Kasibhatla, P., Morton, D., Collatz, G. J., DeFries, R. S., Hyer, E. J., Prins, E. M., Griffith, D. W. T., Wunch, D., Toon, G. C., Sherlock, V., and Wennberg, P. O.: Daily and 3-hourly variability in global fire emissions and consequences for atmospheric model predictions of carbon monoxide, J. Geophys. Res., 116, D24303, doi:10.1029/2011JD016245, 2011.

Murray, L. T., Jacob, D. J., Logan, J. A., Hudman, R. C., and Koshak, W. J.: Optimized regional and interannual variability of lightning in a global chemical transport model constrained by LIS/OTD satellite data, J. Geophys. Res., 117, D20307, doi:10.1029/2012JD017934, 2012.

NADP: National Atmospheric Deposition Program (NRSP-3), NADP Program Office, Illinois State Water Survey, 2204 Griffith Dr., Champaign, IL 61820, 2015.

Neff, J. C., Holland, E. A., Dentener, F. J., McDowell, W. H., and Russell, K. M.: The origin, composition and rates of organic nitrogen deposition: A missing piece of the nitrogen cycle?, Biogeochemistry, 57-58, 99-136, doi:10.1023/A:1015791622742, 2002.

Nemitz, E., Milford, C., and Sutton, M. A.: A two-layer canopy compensation point model for describing bi-directional biosphere-atmosphere exchange of ammonia, Q. J. Roy. Meteorol. Soc., 127, 815-833, doi:10.1002/qj.49712757306, 2001.

Nilsson, J.: Critical Loads for Sulphur and Nitrogen, in: Air Pollution and Ecosystems, edited by: Mathy, P., p. 85-91, Springer Netherlands, available at: http://link.springer.com/chapter/10. 1007/978-94-009-4003-1_11\% (last access: 1 September 2014), 1988.

Olson, J. S.: Digital raster data on a 10 minute geographic 1080 $\times 2160$ grid in Global Ecosystems Database, version 1.0, Disc A, edited by: NOAA Natl. Geophys. Data Center, Boulder, Colorado, 1992.

Pardo, L. H., Fenn, M. E., Goodale, C. L., Geiser, L. H., Driscoll, C. T., Allen, E. B., Baron, J. S., Bobbink, R., Bowman, W. D., Clark, C. M., Emmett, B., Gilliam, F. S., Greaver, T. L., Hall, S. J., Lilleskov, E. A., Liu, L., Lynch, J. A., Nadelhoffer, K. J., 
Perakis, S. S., Robin-Abbott, M. J., Stoddard, J. L., Weathers, K. C., and Dennis, R. L.: Effects of nitrogen deposition and empirical nitrogen critical loads for ecoregions of the United States, Ecol. Appl., 21, 3049-3082, doi:10.1890/10-2341.1, 2011.

Park, R. J., Jacob, D. J., Field, B. D., Yantosca, R. M., and Chin, M.: Natural and transboundary pollution influences on sulfate-nitrate-ammonium aerosols in the United States: Implications for policy, J. Geophys. Res., 109, D15204, doi:10.1029/2003JD004473, 2004.

Paulot, F., Jacob, D. J., and Henze, D. K.: Sources and processes contributing to nitrogen deposition: an adjoint model analysis applied to biodiversity hotspots worldwide, Environ. Sci. Technol., 47, 3226-3233, doi:10.1021/es3027727, 2013.

Paulot, F., Jacob, D. J., Pinder, R. W., Bash, J. O., Travis, K., and Henze, D. K.: Ammonia emissions in the United States, European Union, and China derived by high-resolution inversion of ammonium wet deposition data: Interpretation with a new agricultural emissions inventory (MASAGE_NH3), J. Geophys. Res.-Atmos., 119, 4343-4364, doi:10.1002/2013JD021130, 2014.

Pleim, J. E., Bash, J. O., Walker, J. T., and Cooter, E. J.: Development and evaluation of an ammonia bidirectional flux parameterization for air quality models, J. Geophys. Res.-Atmos., 118, 3794-3806, doi:10.1002/jgrd.50262, 2013.

Reay, D. S., Dentener, F., Smith, P., Grace, J., and Feely, R. A.: Global nitrogen deposition and carbon sinks, Nature Geosci., 1, 430-437, doi:10.1038/ngeo230, 2008.

Sala, O. E., Chapin, F. S., Iii, Armesto, J. J., Berlow, E., Bloomfield, J., Dirzo, R., Huber-Sanwald, E., Huenneke, L. F., Jackson, R. B., Kinzig, A., Leemans, R., Lodge, D. M., Mooney, H. A., Oesterheld, M., Poff, N. L., Sykes, M. T., Walker, B. H., Walker, M., and Wall, D. H.: Global biodiversity scenarios for the year 2100 , Science, 287, 1770-1774, doi:10.1126/science.287.5459.1770, 2000.

Saylor, R. D., Wolfe, G. M., Meyers, T. P., and Hicks, B. B.: A corrected formulation of the Multilayer Model (MLM) for inferring gaseous dry deposition to vegetated surfaces, Atmos. Environ., 92, 141-145, doi:10.1016/j.atmosenv.2014.03.056, 2014.

Schwede, D. B. and Lear, G. G.: A novel hybrid approach for estimating total deposition in the United States, Atmos. Environ., 92, 207-220, doi:10.1016/j.atmosenv.2014.04.008, 2014.

Schwede, D., Zhang, L., Vet, R., and Lear, G.: An intercomparison of the deposition models used in the CASTNET and CAPMoN networks, Atmos. Environ., 45, 1337-1346, doi:10.1016/j.atmosenv.2010.11.050, 2011.

Shephard, M. W., Cady-Pereira, K. E., Luo, M., Henze, D. K., Pinder, R. W., Walker, J. T., Rinsland, C. P., Bash, J. O., Zhu, L., Payne, V. H., and Clarisse, L.: TES ammonia retrieval strategy and global observations of the spatial and seasonal variability of ammonia, Atmos. Chem. Phys., 11, 10743-10763, doi:10.5194/acp-11-10743-2011, 2011.

Stevens, C. J., Dise, N. B., Mountford, J. O., and Gowing, D. J.: Impact of nitrogen deposition on the species richness of grasslands, Science, 303, 1876-1879, doi:10.1126/science.1094678, 2004.

Sullivan, T. J., Cosby, B. J., Tonnessen, K. A., and Clow, D. W.: Surface water acidification responses and critical loads of sulfur and nitrogen deposition in Loch Vale watershed, Colorado, Water Resour. Res., 41, W01021, doi:10.1029/2004WR003414, 2005.
Sutton, M. A., Nemitz, E., Erisman, J. W., Beier, C., Bahl, K. B., Cellier, P., de Vries, W., Cotrufo, F., Skiba, U., Di Marco, C., Jones, S., Laville, P., Soussana, J. F., Loubet, B., Twigg, M., Famulari, D., Whitehead, J., Gallagher, M. W., Neftel, A., Flechard, C. R., Herrmann, B., Calanca, P. L., Schjoerring, J. K., Daemmgen, U., Horvath, L., Tang, Y. S., Emmett, B. A., Tietema, A., Peñuelas, J., Kesik, M., Brueggemann, N., Pilegaard, K., Vesala, T., Campbell, C. L., Olesen, J. E., Dragosits, U., Theobald, M. R., Levy, P., Mobbs, D. C., Milne, R., Viovy, N., Vuichard, N., Smith, J. U., Smith, P., Bergamaschi, P., Fowler, D., and Reis, S.: Challenges in quantifying biosphere-atmosphere exchange of nitrogen species, Environ. Pollut., 150, 125-139, doi:10.1016/j.envpol.2007.04.014, 2007.

Thompson, T. M., Rodriguez, M. A., Barna, M. G., Gebhart, K. A., Hand, J. L., Day, D. E., Malm, W. C., Benedict, K. B., Collett, J. L., and Schichtel, B. A.: Rocky Mountain National Park reduced nitrogen source apportionment: RMNP NITROGEN SOURCE APPORTIONMENT, J. Geophys. Res.-Atmos., 120, 4370-4384, doi:10.1002/2014JD022675, 2015.

UBA: Manual on methodologies and criteria for mapping critical levels/loads and geographical areas where they are exceeded, Federal Environmental Agency (UmweltBundesAmt), available at: http://www.rivm.nl/en/themasites/icpmm/ manual-and-downloads/m\%anual-english/index.html (last access: 19 May 2015), 2004.

van der Werf, G. R., Randerson, J. T., Giglio, L., Collatz, G. J., Mu, M., Kasibhatla, P. S., Morton, D. C., DeFries, R. S., Jin, Y., and van Leeuwen, T. T.: Global fire emissions and the contribution of deforestation, savanna, forest, agricultural, and peat fires (19972009), Atmos. Chem. Phys., 10, 11707-11735, doi:10.5194/acp10-11707-2010, 2010.

Vitousek, P. M., Aber, J. D., Howarth, R. W., Likens, G. E., Matson, P. A., Schindler, D. W., Schlesinger, W. H., and Tilman, D. G.: Human alteration of the global nitrogen cycle: sources and consequences, Ecol. Appl., 7, 737-750, doi:10.1890/10510761(1997)007[0737:HAOTGN]2.0.CO;2, 1997.

Vries, W. D., Wamelink, G. W. W., Dobben, H. v., Kros, J., Reinds, G. J., Mol-Dijkstra, J. P., Smart, S. M., Evans, C. D., Rowe, E. C., Belyazid, S., Sverdrup, H. U., Hinsberg, A. v., Posch, M., Hettelingh, J.-P., Spranger, T., and Bobbink, R.: Use of dynamic soilvegetation models to assess impacts of nitrogen deposition on plant species composition: an overview, Ecol. Appl., 20, 60-79, doi:10.1890/08-1019.1, 2010.

Walker, T. W., Jones, D. B. A., Parrington, M., Henze, D. K., Murray, L. T., Bottenheim, J. W., Anlauf, K., Worden, J. R., Bowman, K. W., Shim, C., Singh, K., Kopacz, M., Tarasick, D. W., Davies, J., Gathen, P. v. d., Thompson, A. M., and Carouge, C. C.: Impacts of midlatitude precursor emissions and local photochemistry on ozone abundances in the Arctic, J. Geophys. Res., 117, D01305, doi:10.1029/2011JD016370, 2012.

Wang, Y., Jacob, D. J., and Logan, J. A.: Global simulation of tropospheric $\mathrm{O}_{3}-\mathrm{NO}_{x}$-hydrocarbon chemistry 3 . Origin of tropospheric ozone and effects of nonmethane hydrocarbons, J. Geophys. Res., 103, 10757-10767, doi:10.1029/98JD00156, 1998.

Wang, Y. X., McElroy, M. B., Jacob, D. J., and Yantosca, R. M.: A nested grid formulation for chemical transport over Asia: Applications to CO, J. Geophys. Res., 109, D22307, doi:10.1029/2004JD005237, 2004. 
Wecht, K. J., Jacob, D. J., Wofsy, S. C., Kort, E. A., Worden, J. R., Kulawik, S. S., Henze, D. K., Kopacz, M., and Payne, V. H.: Validation of TES methane with HIPPO aircraft observations: implications for inverse modeling of methane sources, Atmos. Chem. Phys., 12, 1823-1832, doi:10.5194/acp-12-1823-2012, 2012.

Wesely, M.: Parameterization of surface resistances to gaseous dry deposition in regional-scale numerical models, Atmos. Environ. (1967), 23, 1293-1304, doi:10.1016/0004-6981(89)901534, 1989.

Yienger, J. J. and Levy, H.: Empirical model of global soilbiogenic NOx emissions, J. Geophys. Res., 100, 11447-11464, doi:10.1029/95JD00370, 1995.

Zhang, L., Jacob, D. J., Downey, N. V., Wood, D. A., Blewitt, D., Carouge, C. C., van Donkelaar, A., Jones, D. B. A., Murray, L. T., and Wang, Y.: Improved estimate of the policyrelevant background ozone in the United States using the GEOS-Chem global model with $1 / 2^{\circ}-2 / 3^{\circ}$ horizontal resolution over North America, Atmos. Environ., 45, 6769-6776, doi:10.1016/j.atmosenv.2011.07.054, 2011.
Zhang, L., Jacob, D. J., Knipping, E. M., Kumar, N., Munger, J. W., Carouge, C. C., van Donkelaar, A., Wang, Y. X., and Chen, D.: Nitrogen deposition to the United States: distribution, sources, and processes, Atmos. Chem. Phys., 12, 4539-4554, doi:10.5194/acp-12-4539-2012, 2012.

Zhu, L., Henze, D. K., Cady-Pereira, K. E., Shephard, M. W., Luo, M., Pinder, R. W., Bash, J. O., and Jeong, G.-R.: Constraining U.S. ammonia emissions using TES remote sensing observations and the GEOS-Chem adjoint model, J. Geophys. Res.-Atmos., 118, 3355-3368, doi:10.1002/jgrd.50166, 2013.

Zhu, L., Henze, D., Bash, J., Jeong, G.-R., Cady-Pereira, K., Shephard, M., Luo, M., Paulot, F., and Capps, S.: Global evaluation of ammonia bidirectional exchange and livestock diurnal variation schemes, Atmos. Chem. Phys., 15, 12823-12843, doi:10.5194/acp-15-12823-2015, 2015. 